\title{
نشأة العلوم الإسلامية وتطورها: \\ تأسيس علم مقاصد الشريعة أنموذجاً
}

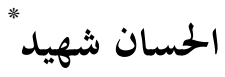

$$
\begin{aligned}
& \text { الملخص } \\
& \text { قد يسهم النظر في الأسس التاريخية والجذور المعرفية لنشوء العلوم الإسلامية في فهـــم بعـــ الإشـــالات }
\end{aligned}
$$

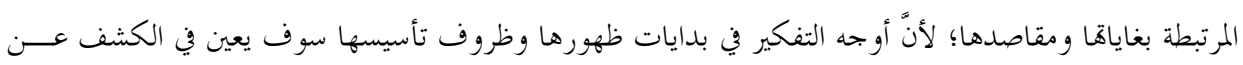

$$
\begin{aligned}
& \text { العو امل المؤثرة في عمل العقل الباحث، وتقديم إشارات حول المقاصد التي رسمها الفكر الإنساني لتلك العلوم. مثل } \\
& \text { هذا التأسيس النظري يعين في الإجابة عن أسئلة تختص بإمكانية إنشاء علوم جديدة كعلم مقاصد الشريعة، وبيــان } \\
& \text { مدى صحة ذلك في النظر العلمي، وثباته في الواقع الوجودي بين العلوم من حيث الضرورات و المسوغات. } \\
& \text { الكلمات المفتاحية: نشأة العلوم، العلوم الأصلية، العلوم التبعية، أصول الفقه، مقاصد الشريعة. }
\end{aligned}
$$

\section{The Emergence and Development of Islamic Sciences: The Establishment of Maqasid al-Shariah as a Model}

\begin{abstract}
Analyzing epistemological and historical foundations of the rise of Islamic sciences may contribute to a better understanding of issues associated with their objectives. Thinking about the early appearances and the circumstances of the Islamic sciences would help identify determinant factors of the inquiring mind and provide references for the objectives laid out for these sciences by human thought.

On the basis of this theoretical ground, issues related to the emergence of these sciences arise, the most critical of which is the possibility of founding new sciences such as the Objectives of Islamic Law. The paper tries to answer questions related to the way in which various sciences have been established in Islamic thought and the values behind establishing such sciences.
\end{abstract}

Keywords: Emergence of Islamic Sciences, Primary Sciences, Secondary sciences, Usul Fiqh, Maqasid al-Shariah.

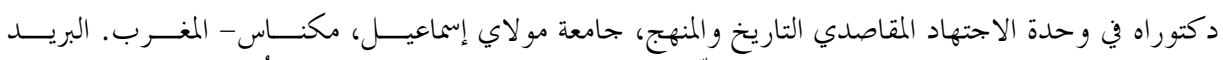

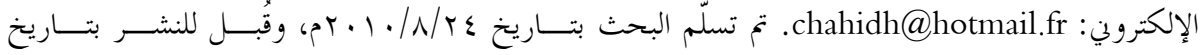


مقدمة:

قد يسعف النظر في الأسس التاريخية والجذور المعرفية لنشوء العلوم الإنســانية، في

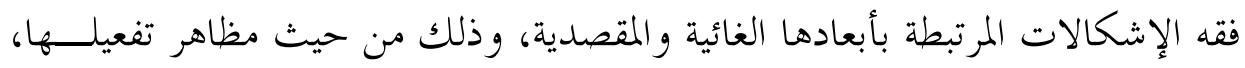

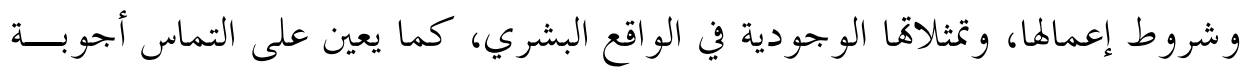

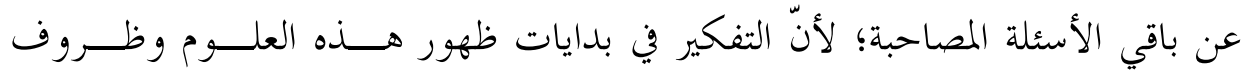

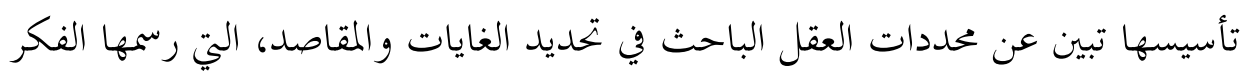

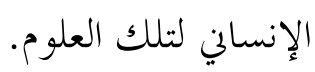

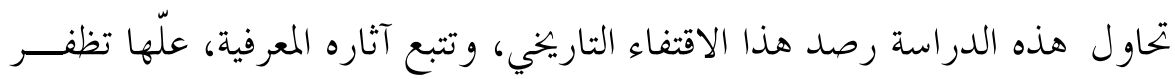

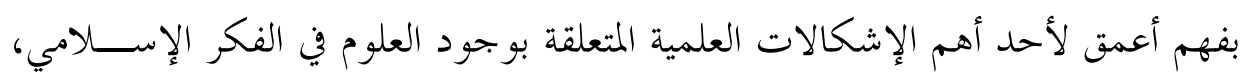

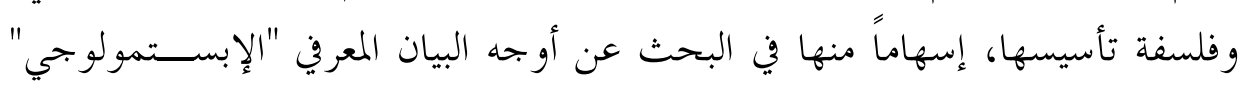
لتلك القضايا.

وعلى هذا التأسيس النظري تظهر إشكالات لها ارتباط بنشأة العلوم، من أهمهــا:

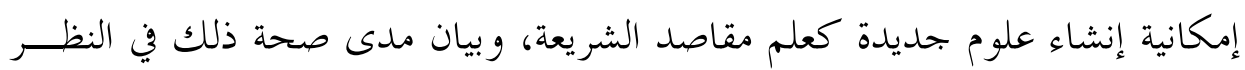

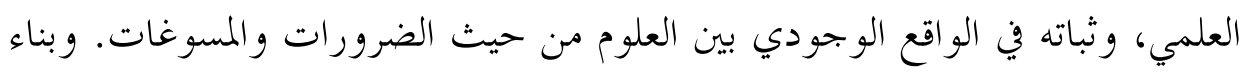
عليه تتمحور الدراسة حول التساؤلات الآتية:

كيف تم إنشاء العلوم في الفكر الإسلامي؟ وما هي الأسس العلمية والمنهجية التي

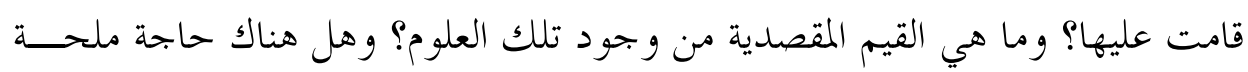

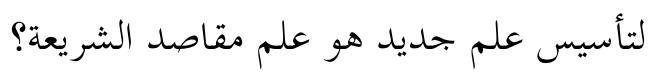

\section{أولاً: في تاريخ العلوم ونشأقها؛ العلوم الإسلامية الأصلية والتبعية}

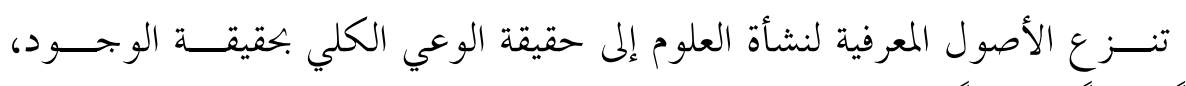

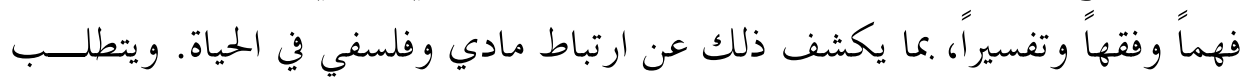

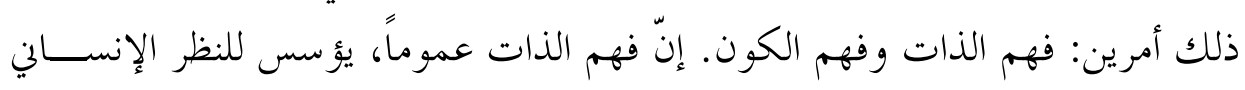




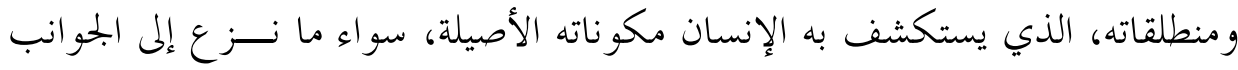

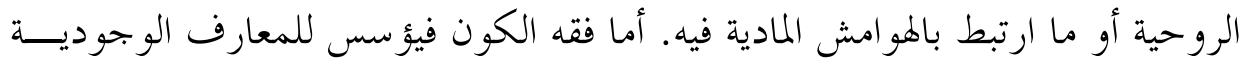
و الإلهية القائمة على توجيه الأنظار في العلاقة الوثيقة بين التمثل الثقـــافي للإنســـان، و المعرفة الاعتقادية في الوجود، في حين يشير تفسير ذلك الإدراك إلى إنتاج معـــارف علمية تخضع للتفسير الفلسفي لحيط الإنسان، و بيان حقائق الاجتماع البشري. فكانت كل العلوم الناشئة والمتفرعة عنها تنتهي أبعادها المعرفية في استيعاب الحقائق الإنسانية، و خحدة و جو دها بالفعل، و امتداد حضورها بالقوة.

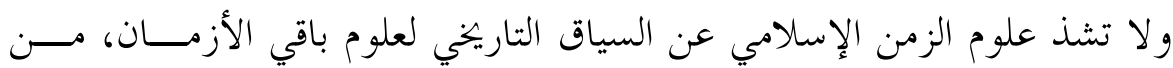

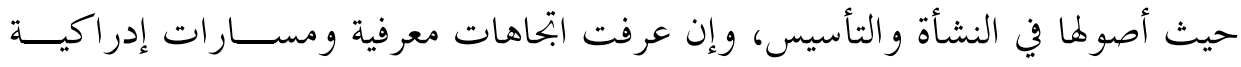

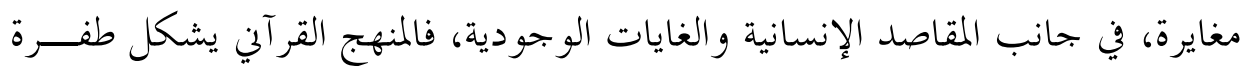

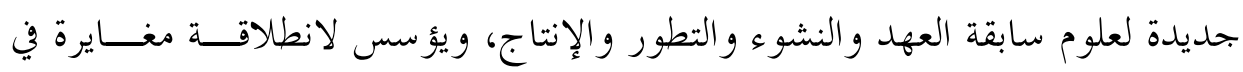

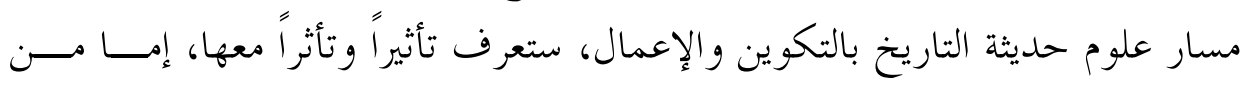
حيث التكامل المعرفي، أو من حيث الاستعارة المنهجية أو التقصيد الكولي. إنَّ مهمة الاستئناف الثقافي والحضاري التي شغلت العقل الإسلامي بآلياته العلمية و المعرفية، هي التي رسمت خارطة سبل إنشاء العلوم الإسلامية بخصائص مميزة، وأدوات

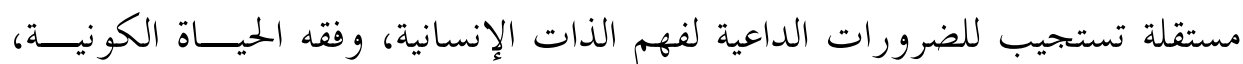
وتفسير القضايا الكلية للعلاقة بين الإنسان و النص و الوجود. ومن الميزات اللافتة في ظهور العلوم الإسلامية، أنَّ أغلبها -إن لم تكن كلها- تم

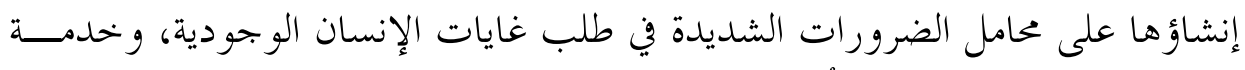

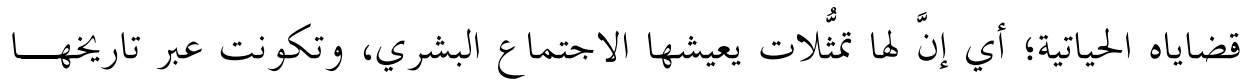
المعري وهي تحمل في داخلها عوامل استمر ارها وقوة بقائها، و يبدو ذلك في تفتق علوم

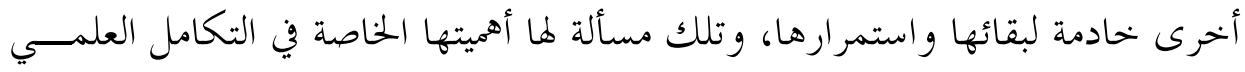
و المعر في "الإبستمولوجي" للعلوم الإسلامية. 
تستوقف الدارس لتاريخ العلوم الإسلامية منذ نشأقةا ومسالك تطورهـــــا ثـلاثل

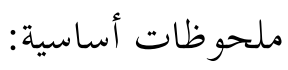

ا. أغلب هذه العلوم تفتقت بدايتها في نست عملي وظيفي في مو اقع الوجـــود،

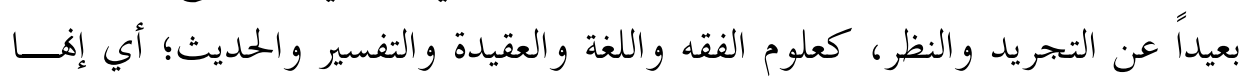
علوم استصحبت بنيتها مع تفاعلات الإنسان و الكون. r. أغلب هذه العلوم ما إن تطور هـا الزمن، واشتدت هـا أحوال الإنسان، حستى

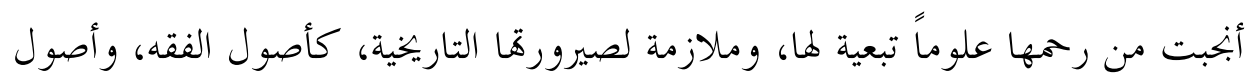

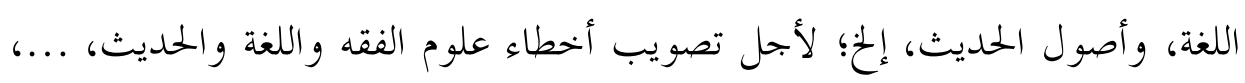
وتسوية مسارها.

بـ هذه العلوم عرفت تراجعاً بين الفينة والأخرى، وأبعدةا العوامل الناشئة عــن

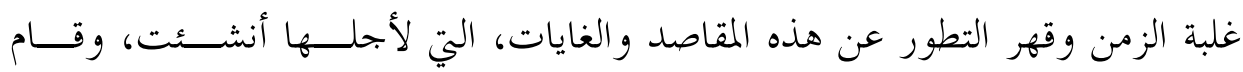

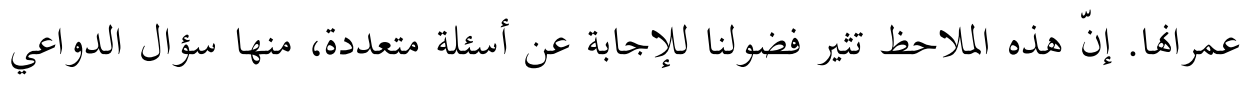

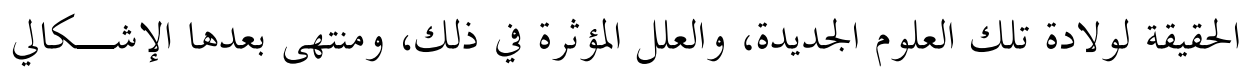

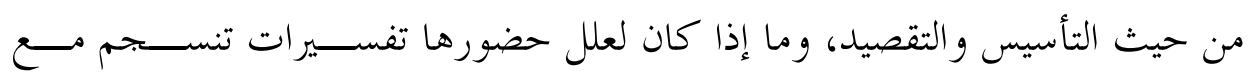
حقائقها الأولى ومبادئها الإنشائية؟ ونئ

تفصح القاعدة السُّنية في التاريخ البشري عن استحالة إنشاء علم مـــن العلـــوم

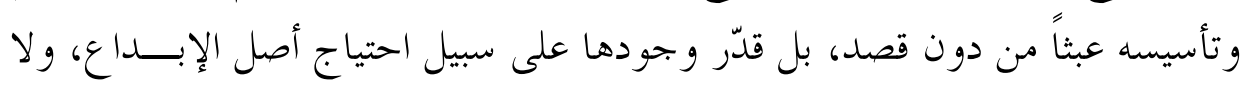

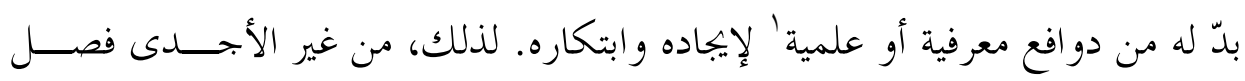

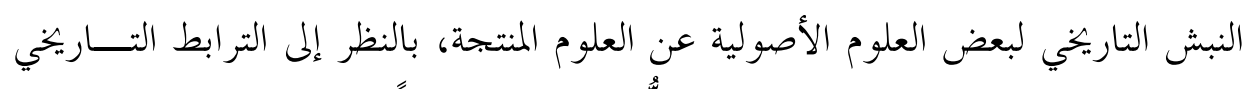

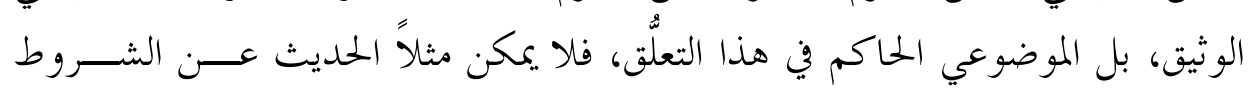

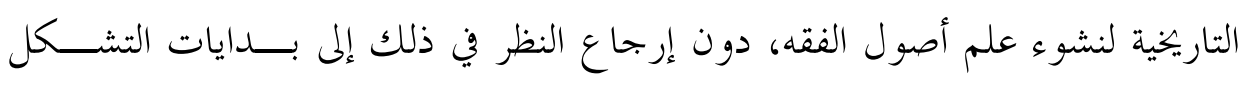

' لمزيد من التفصيل يمكن النظر في:

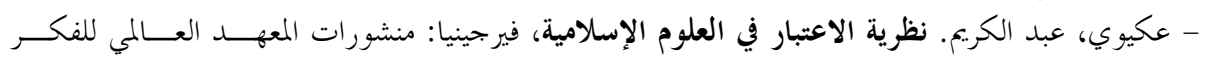

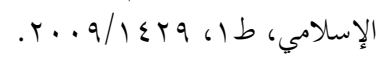


الموضوعي لعلم الفقه، وهكذا مع علم اللغة وأصول اللغة، وعلم الحـــــيث وأصــــل الحلديث.

إنَّ الظهور المتأخر للعلوم "الأصولية" أو التبعية الضابطة بلحالاها الأصلية، يؤكد أن

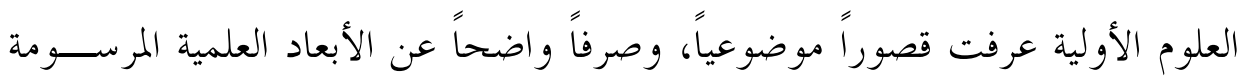

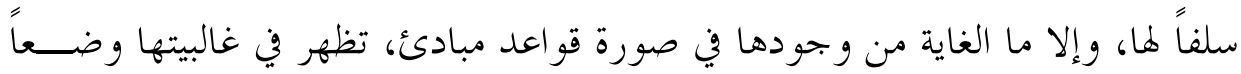

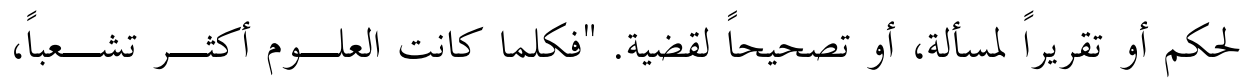
و الناظرون فيها مضطرون في الوقوف عليها إلى أمور لم يضطر إليها مـــن تقــــــمهم،

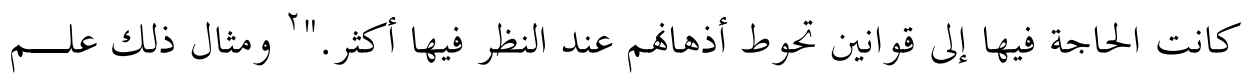

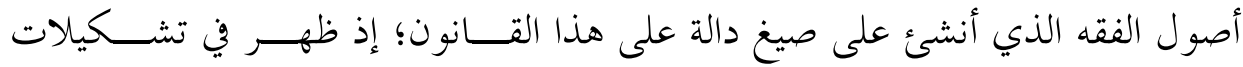
قو اعده المؤكدة وعبار اته الجازمة في البيان و التقرير.

ثانياً: العلوم الإسلامية، بداية تشكُّها ومقاصدها الوجودية ا ـ الوحي وتفتُّق العلوم الإسلامية:

أزعم أن بدايات تشكل العلوم في الفكر الإسلامي يعود إلى علوم خمسة، كــان

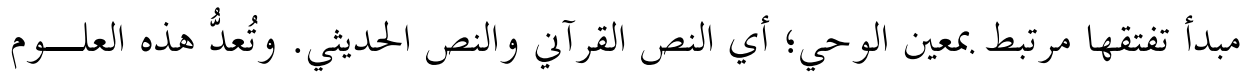
أساس كل العلوم الأخرى المتناسلة عنها عبر السياق التاريخي، وهي المطلوبة بالاعتبار

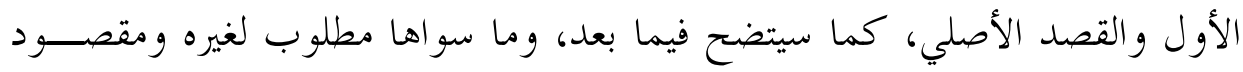
على سبيل الوساطة والاستخدام.

وتنتظم هذه العلوم ضمن خصوصيات النسق الوجودي والتفصيلي لحياة الإنسان المسلم، التي يجمعها ناظم إنساني متكامل في علاقته مع الكون و الوجود، تنتهي أبعادها

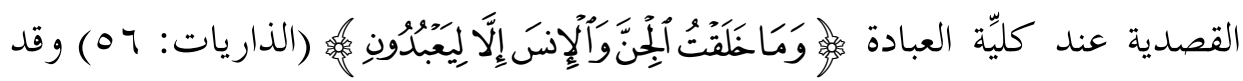

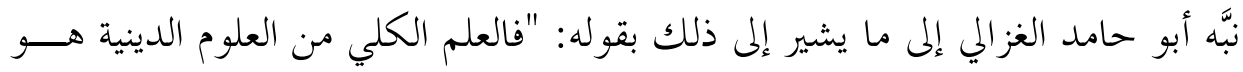
r بابن رشد، أبو الوليد. الضروري في أصول الفقه، تحقيق: جمال الدين العلوي، بيروت: دار الغرب الإســلامي، 


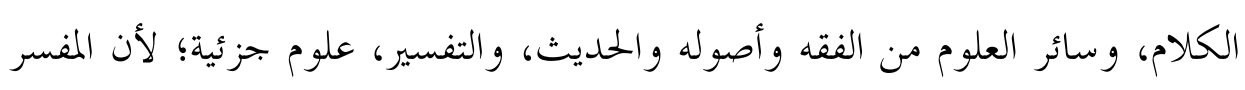

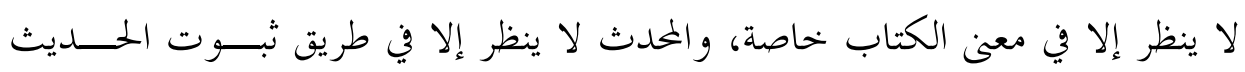

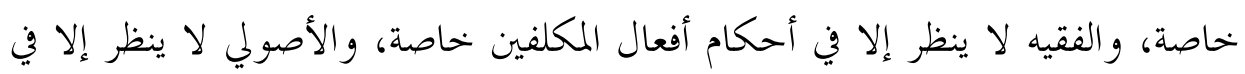

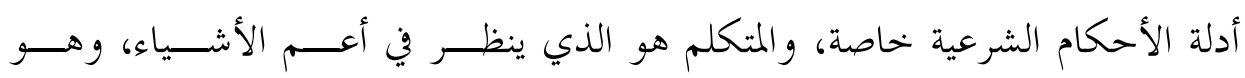

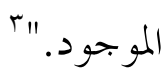

فما هي المواقع المعرفية والحضارية لذه العلوم الأساسية الاعتبار، ضمن أطــــاف

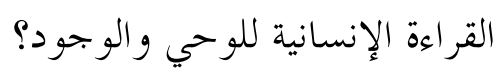

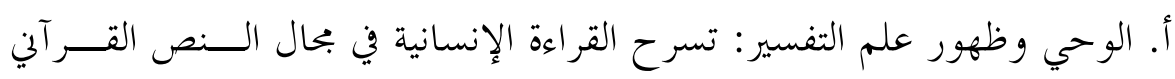

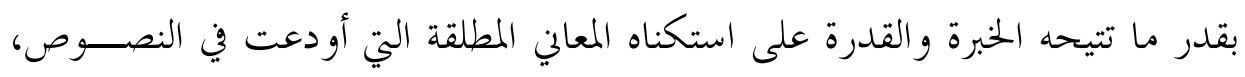
وذلك ما خلص إليه العقل التفسيري، الذي لم يعط مفاتيحه إلا لمن أوتي تشـــــيفاً لا يحوزه كثير من الناس، فكانت بذلك البداية الحقيقية لعلم التفسير، الذي إليه ترد كافة

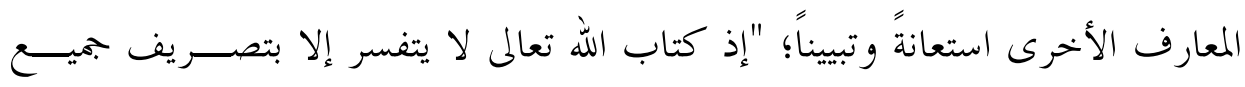
العلوم فيه. "أ

وعلى امتداد التلاوة الكلية للنص القرآي كان لزاماً استحضـــار أسـسـس الفهـــم الإنساني للخطاب الإلهي، من حيث تفسير معانيه الكبرى، وتأويلها وفـــق القضــــايا

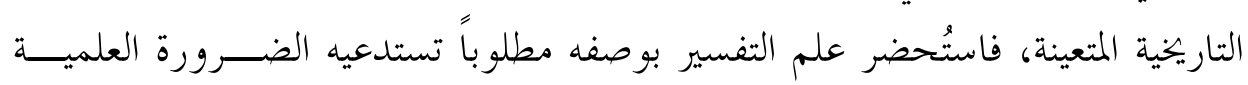

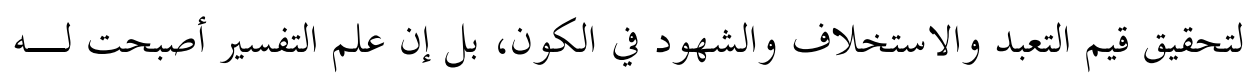

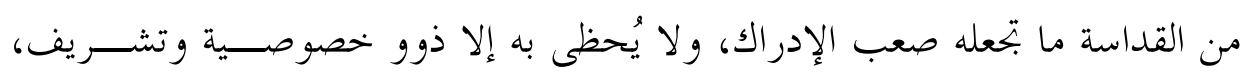

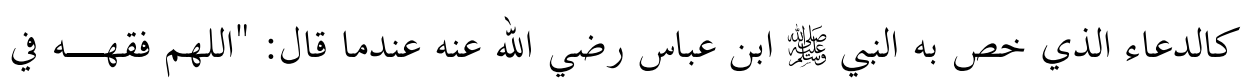

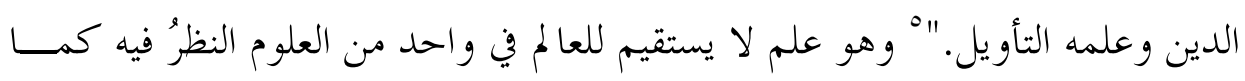

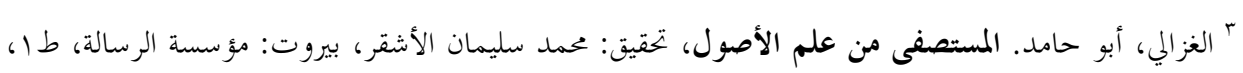

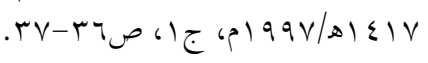

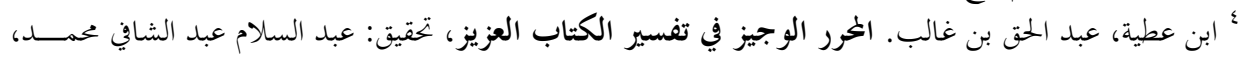

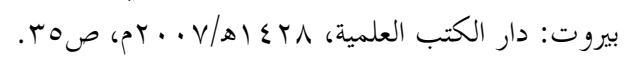

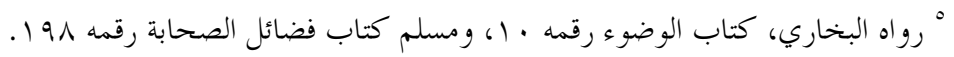


قال الزخشري: "إن أملأ العلوم بما يغمر القرائح، وأهضها بما يبهر الألباب القوارح من

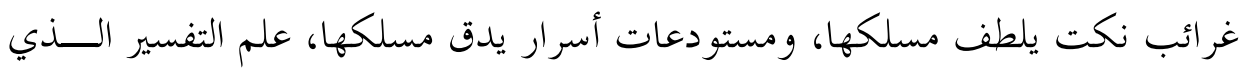

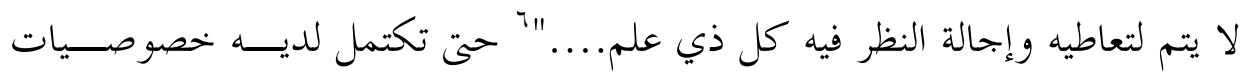
القراءة في الكتاب الموجبة لفقه الحياة والكون.

ب. الوحي والسُّنة وعلم الحديث: و السنة هي الامتداد الشرعي للنص القــــــي

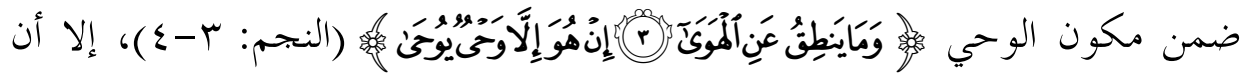

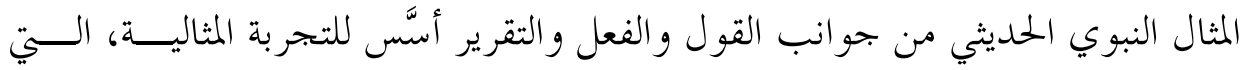

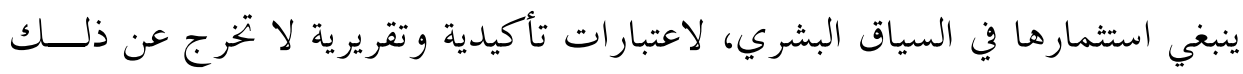
النسق، وهو الأمر الذي عجَّل بظهور علم الحديث وفقهه. ولئن تأخرت العناية بالحديث الشريف كتابةً وحفظاً و تدويناً، فإنّ استحضاره في صيرورة التعبد والفهم السليم للنص القرآي، بدا جلياً في مصاحبة الجيل الفريد للـــبي

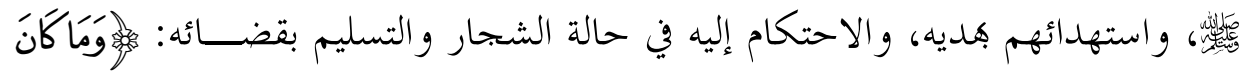

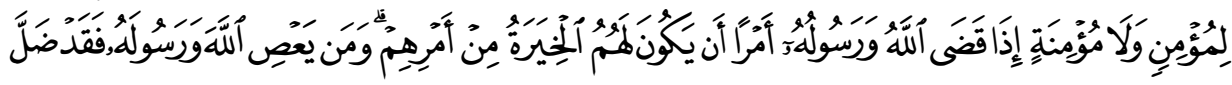

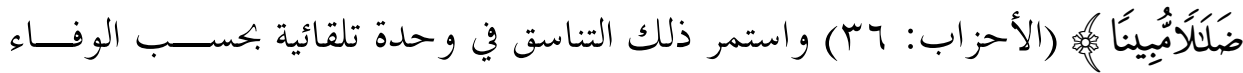
للنص الحديثي وفاء ضمنياً للنص القرآين. ت. الوحي والغاية من خلق الإنسان: ترسو مطالب القراءة المعرفية للنص القرآي، بناء على علم التفسير عند المعاني المقصودة بالقصد الأصلي من خلق الإنسان ابتـــداء، و تستعين في فقه القضايا العقدية والإيمانية للإنسان التي تيسر سبل العبـــادة والتـــــين،

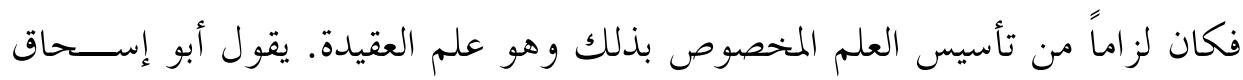

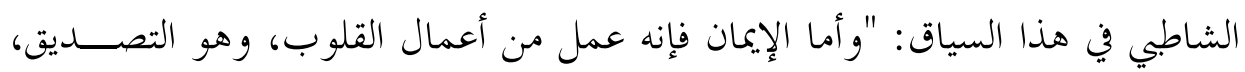
وهو ناشئ عن العلم، والأعمال قد يكون بعضها وسيلة إلى بعض، وإن صح أن تكون مقصودة في أنفسها، أما العلم فإنه و سيلة، وأعلى ذلك العلم بالله، ولا تصح به فضيلة

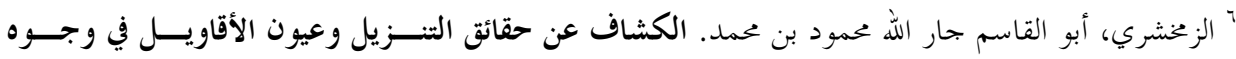

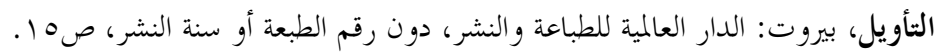




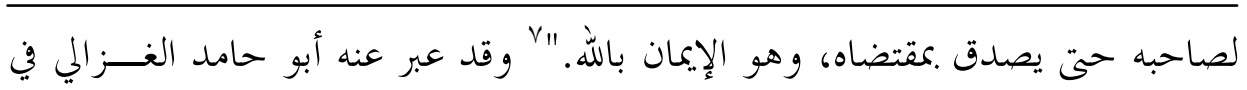
النص السابق بالعلم الكلي من العلوم الدينية.

ولا تنفك الاستعانة بعلم العقيدة عن الشروط الموضوعية لنشوء علمــي الفقــــ و التفسير، بوصفه يملأ فقرة مهمة في الحضور الإنساني المتكامل للاستخلاف، ويتمثـلـل

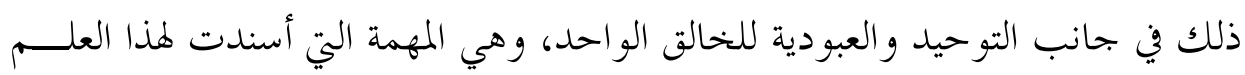
منذ بداياته الأولى. وعليه؛ فإن قضايا الإيمان و التوحيد و الربو بية وبيان العقيدة الجلديدة عُلَّت جورهية في ترسيخ مبدأ التعبد الإنساني.

وبتحر الإشارة هنا إلى أن علم العقيدة المقصود هنا، ليس هو علم الكالام أو علم

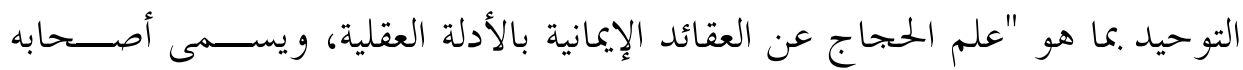

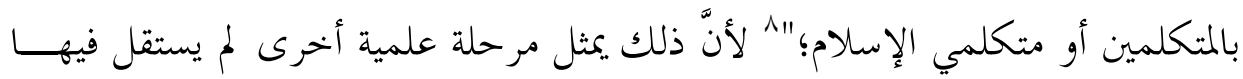
علم العقيدة عن بحاله بعد.

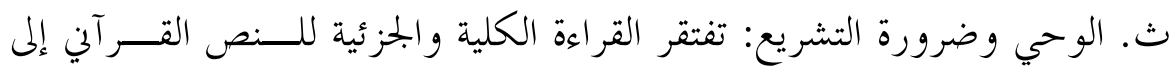

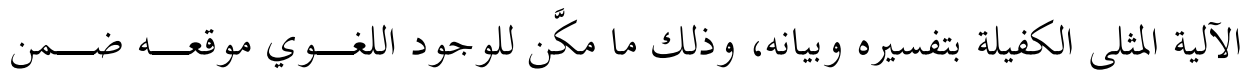

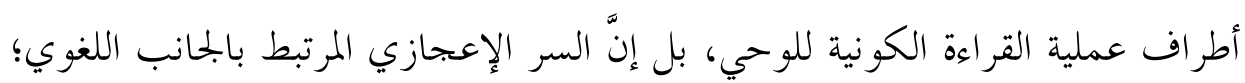

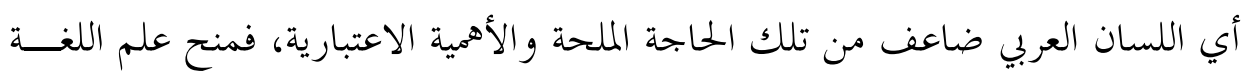
أحقيته في مشروع البداية مع تلك العلوم القارئة.

ولا يمكن التشكيك في التمكين اللغوي للسان العربي في مرحلة ما قبل الوحي، إلا أن ثباته الوجودي من جانب الفعل والقوة لن يستقيم إلا مع الفرض القرآي آلمتمثل في

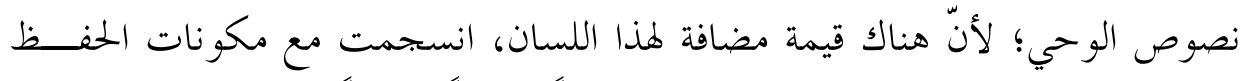

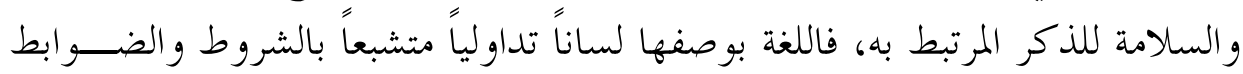

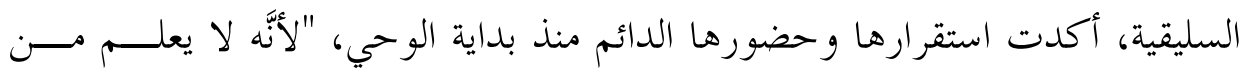

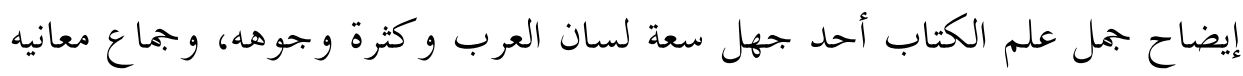
^الشاطبي، أبو إسحاق. الموافقات في أصول الشريعة، تحقيق: عبد الله دراز، بــيروت: دار الكتــب العلميــة،

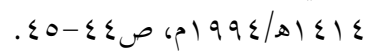
^ النشار، علي سامي. نشأة الفكر الفلسفي في الإسلام، مصر: دائرة المعارف، ط9، 990 (م، ج)، ص^ء. 


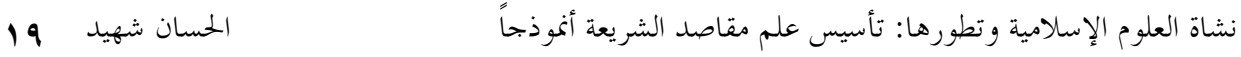

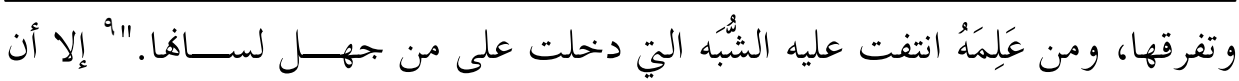

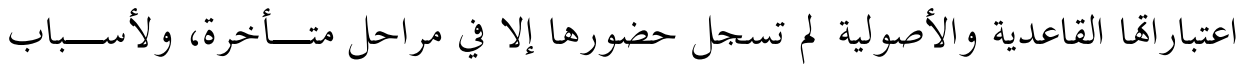

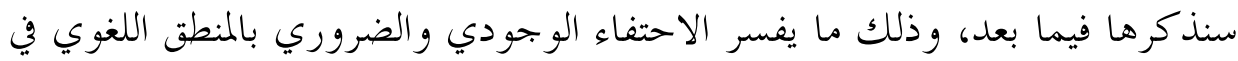

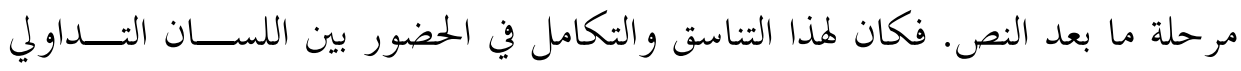

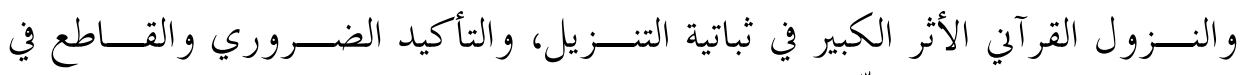
ضمان استمرارية حفظ الذِّر

ج. الوحي؛ فقه النص وبيانه العملي: يتمثل القصد الوسيط أو المطلوب من فعـل

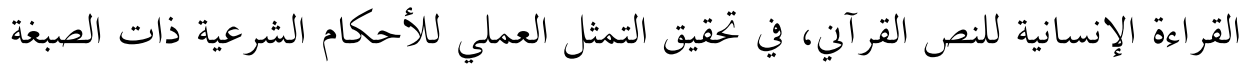

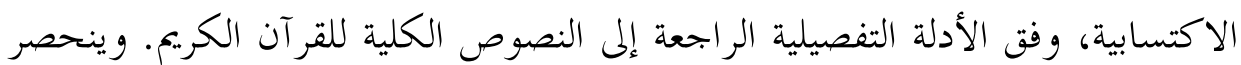

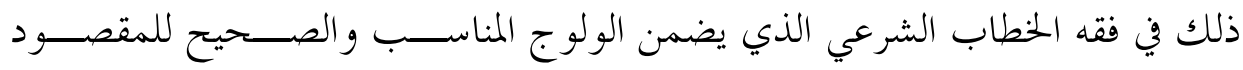

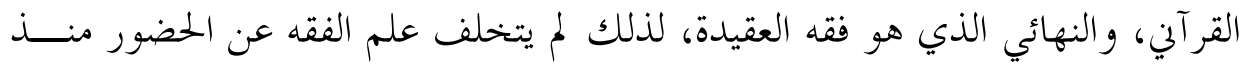
البدايات الأولى للحضور النص الشي الشرعي.

وقد نشأت المعرفة الفقهية في البدء على ضرورة فقه الخطاب الشرعي العام، الذي

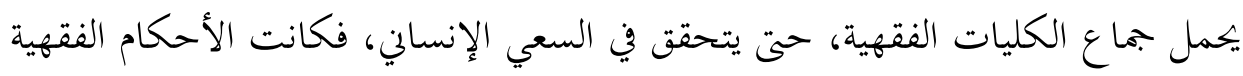

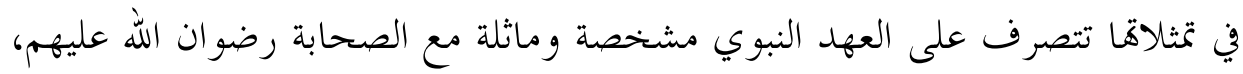

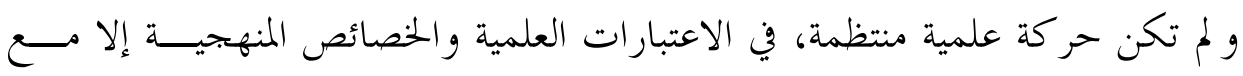

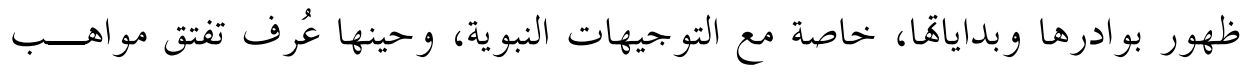
بعض الصحابة حسب كل علم.

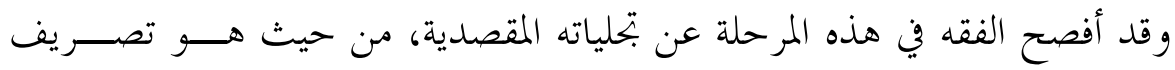
عملي للأحكام الشرعية في الواقع الإنساني، يطلب به المسلم مقصد العبادة والتســـبيح

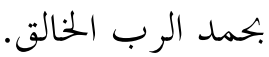

\section{Y. تصنيف العلوم ومراتب الوظيفة:}

سبقت الإشارة إلى أن كل العلوم المرتبطة بالمحال التداولي الإســالامي تعــود في

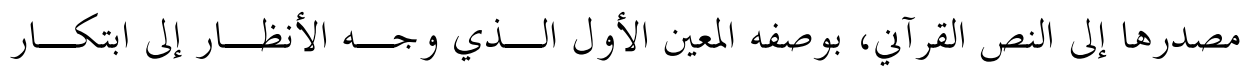


المعارف، واستنباط الأصول الخادمة على القصد الأول من النــزول و التنــزيل؛ الذي الذي

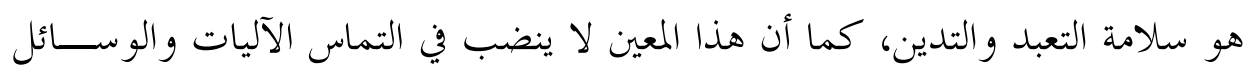

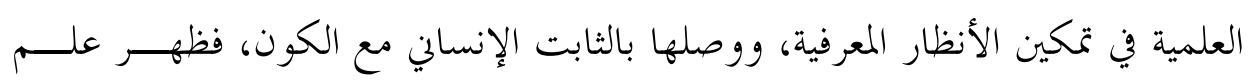
الفقه، و نشأ علم الحلديث، وابتكر علم العقيدة، وعلم اللغة، وعلم التفسير. إن التشابك التاريخي بين العلوم، والتداخل المعري بينها منذ نشأهّا، يحاصــــا في

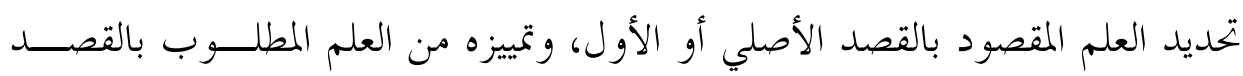

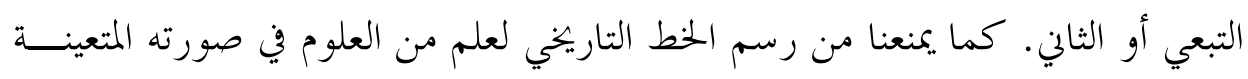

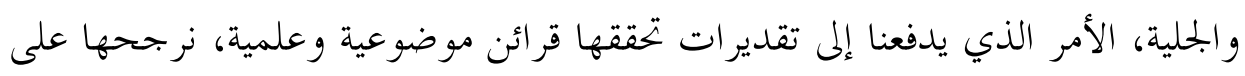
الظن الغالب. و بناء عليه يمكن تصنيف هذه العلو م إلى صنفين: أ. علوم أصلية: وهي العلوم التي نشأت ابتداءً على أساس الاستيعاب و التحقــق

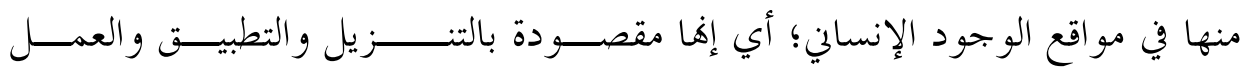
الإفرادي. ويدخل في ذلك علم التفسير وعلم الفقه وعلم العقيدة وعلم اللغة، وغـــير

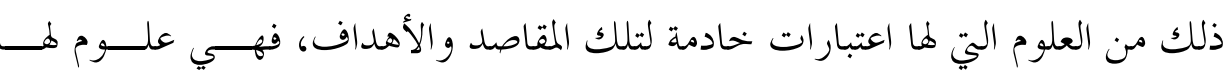

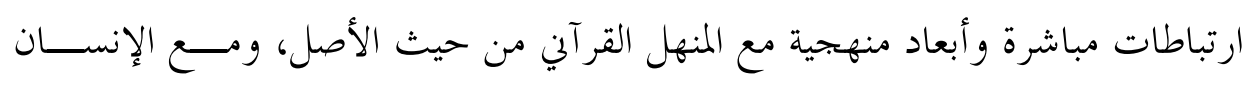
المتلقي من حيث العمل و الإعمال.

ب. علوم تبعية: وهذه العلوم توصف بالعلم على سبيل الجو از؛ لأنبها اســتحدثت

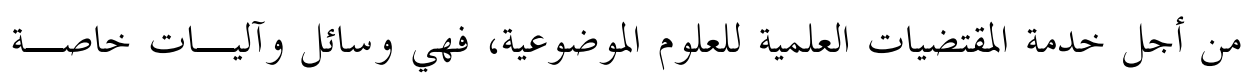

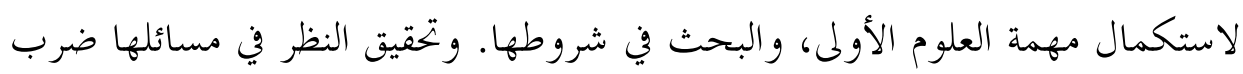

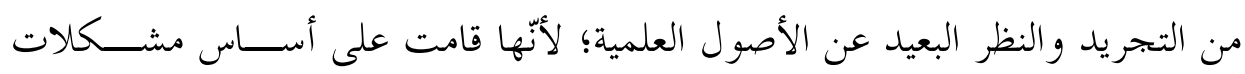

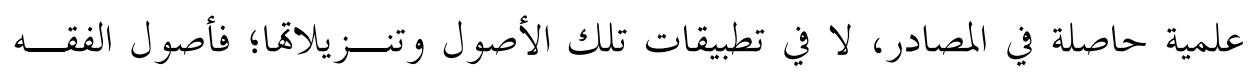
مثلاً تم تأسيسه بعدما حل الضعف في الإمكانات العملية للفقه، وقصوره عن استكمال

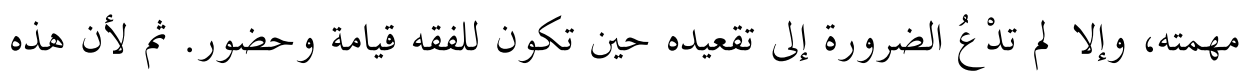

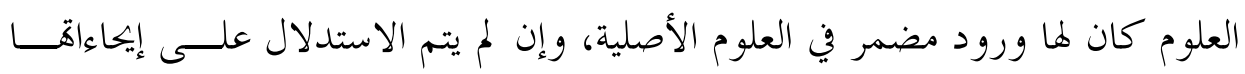


بصورة واضحة ومتعينة، فهي جزء لا يتجزأ منها. وبتحريدها عن جــــورها نظــــ في الغالب يجانب سلامة النظر وصحة العلم.

كما أن مقتضيات الشروط الواقعية و الضرورة الشرعية التي أملت العناية اللازمـــــ

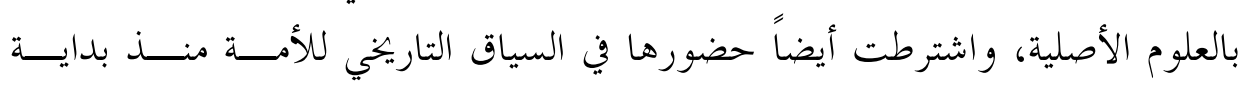
الرسالة، جعلت تلك العلوم رهينة بالتطوير و التقصيد العملي على مســتوى التمثـــل و العمل. وهذه المقتضيات نفسها استصحبت في تسويغ الاعتبار العلمي للعلوم المنظمة

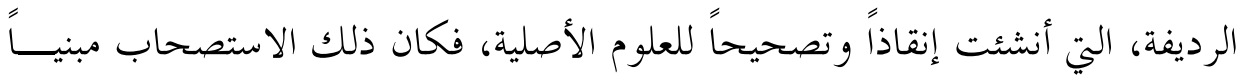

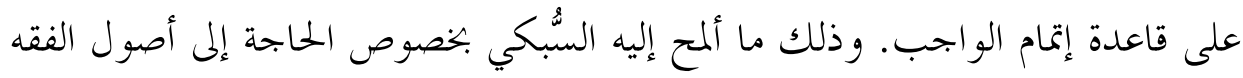

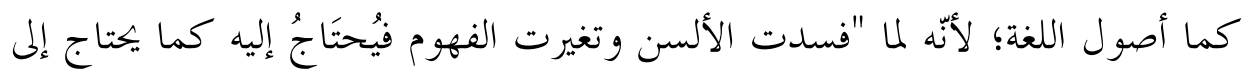

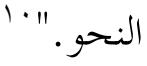

إذن شكّلت العلوم الأولية؛ أي أمهات العلوم الواجب حفظها والعناية هـا، دراسة

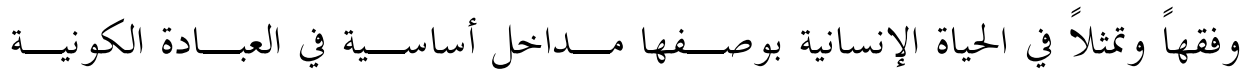

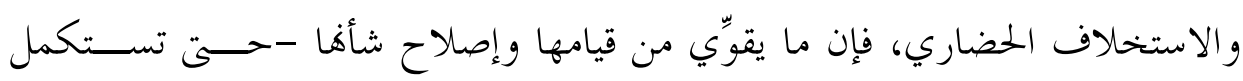

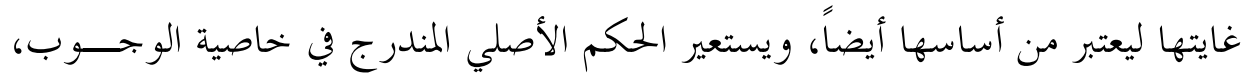

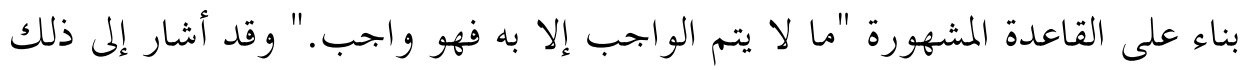
الشاطبي في قاعدة احترازية من دخول ما لا ينبين عليه عمل قائلاً: "كل مسألة لا ينبين

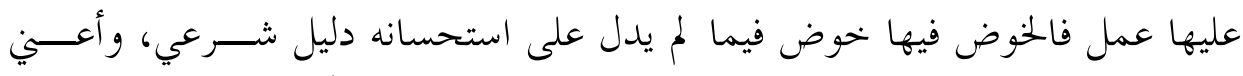

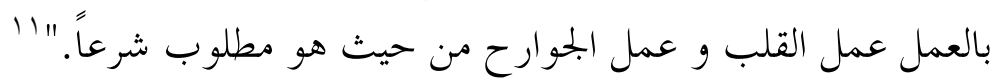

لذلك فإن تمامية الو اجب المتعين في قيامة تلك العلوم و ازدهارها، وفق المتطلبــات الأساسية في الكون و الوجود، تطال العلوم الضابطة المركبة إضافياً مع الأصول، كعلم أصول الفقه وأصول الحديث وأصول اللغة وأصول التفسير وأصول العقيدة، التي ينبغي

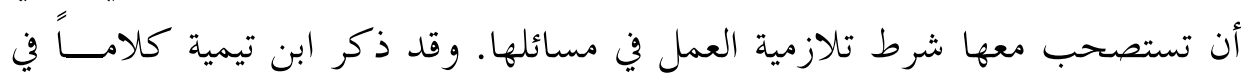

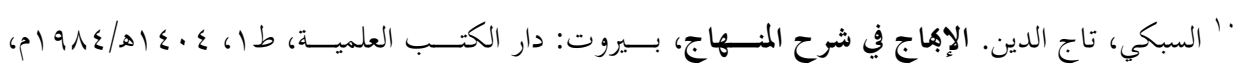
" الشاطبي. المو افقات في أصول الشريعة، مرجع سابق، ص آم. 
هذا السياق يقضي فيه بوجوبية الإعمال الفهمي للغة في فقه الخطاب الشرعي، وذلك

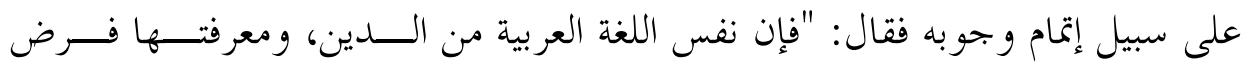

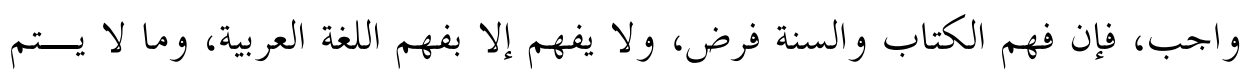

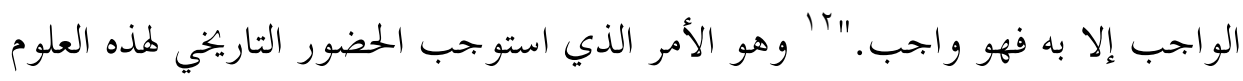
و إنشائها على سبيل التقصيد العلمي، بحفظ المعارف العلمية المشخصة، وتفعيلــــا في في الفقه و التفسير و الحلديث و اللغة و العقيدة.

\section{ب. تشكّل العلوم في القيم المقصدية:}

لعلوم الزمن الإسلامي خصوصية متفردة عن غيرها، تتمثل في معادهـــــالأول إلى معين الوحي ونصوصه الملازمة له؛ لأنّ وجودها الفعلي ارتبط ببداية الرسالة القرآنية، وتكونت في رحم التاريخ النبوي المصاحب لها، الأمر الذي يجعل النظر في تاريخ العلوم يربط استحداثها من حيث المقاصد العلمية مع القيم الكبرى الخاصة بتلك الرسالة. يتحقق السياق الوجودي للعلوم الإسلامية الكبرى الحاكمة، وهي علم الفقه وعلم التفسير وعلم العقيدة وعلم الحديث وعلم اللغة في تناغمها مع كليات مقصدية، وهي التعبد الإلهي و الاستخلاف الأرضي و الشهود الإنساني.

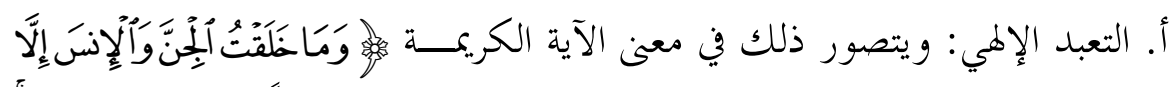

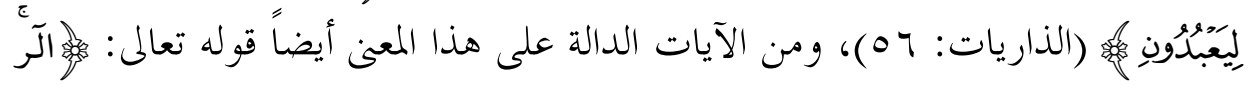

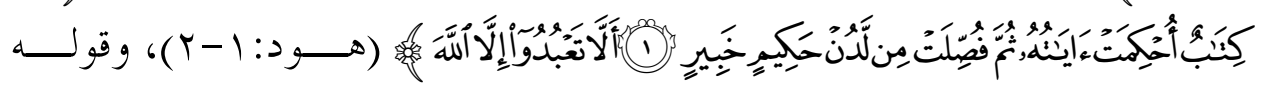

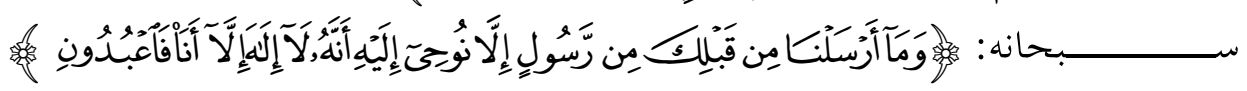

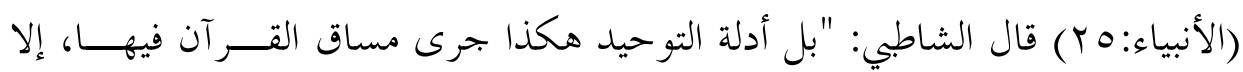

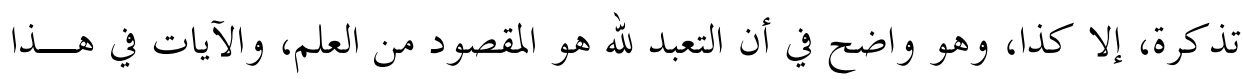

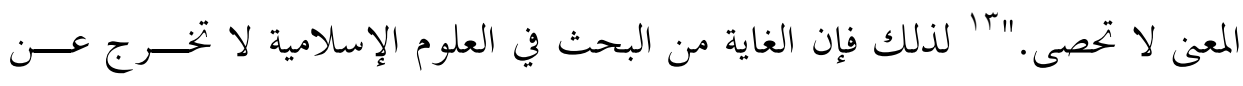

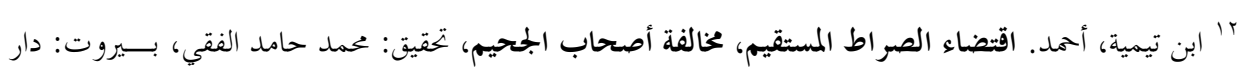

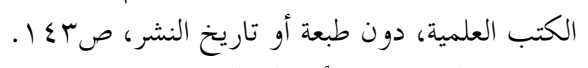

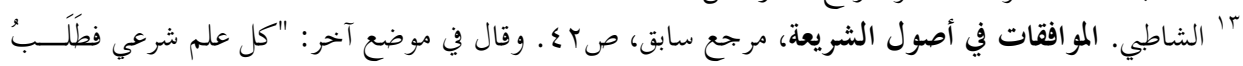

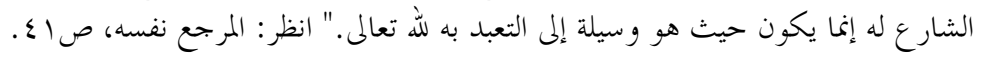


خدمة العقيدة، ا "وما تم ذلك إلا بتكون الذهنية الإسلامية على مبدأ التوحيد المعرفي المتأتي من التوحيد الإيماني، الذي سلك قدرات الإنسان المعرفية في خط واحد، وهو ما جعلها تتجه إلى الله الواحد في كل ما تروم من الحقيقة."

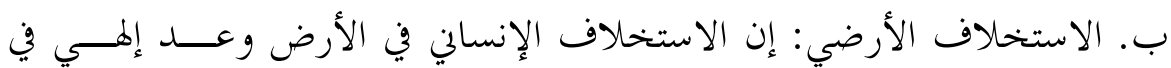

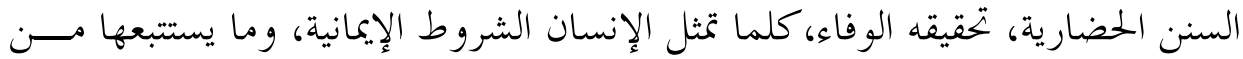
لواحق العمل ذي القيم الصالحة في الأرض وبين الناس، وهو المقصد الأسمى من تفعيل

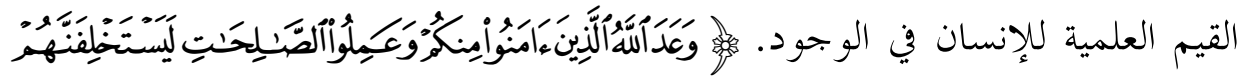

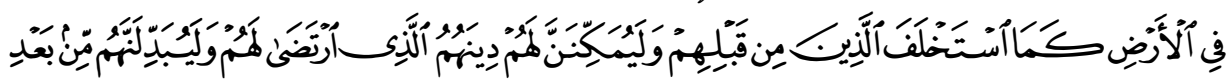

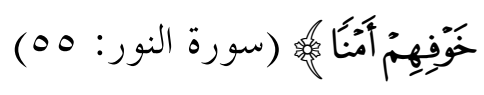

ت. الشهود الإنساني: يبقى الشهود الثقافي فاية التكليف الإلهي لإنسان، وغاية استحقاقات الوفاء بالأمانة المعروضة عليه، ثم إن الأمة بما هي مستأمنة في الوجود

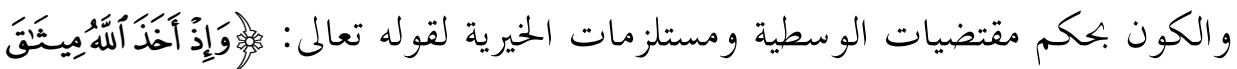

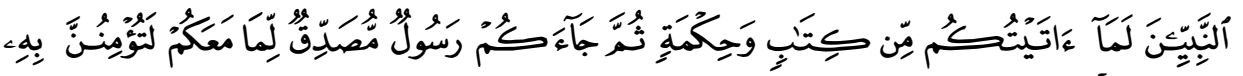

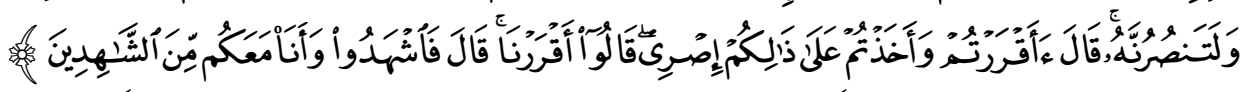

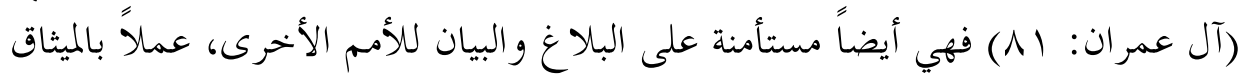

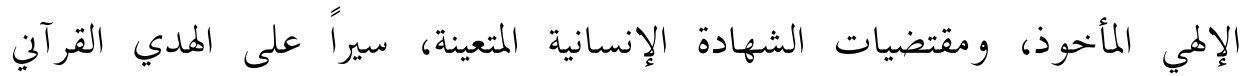

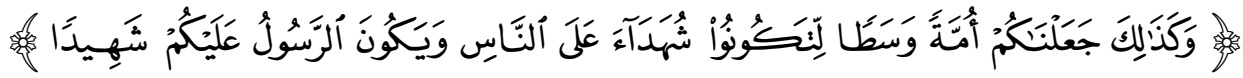

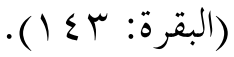

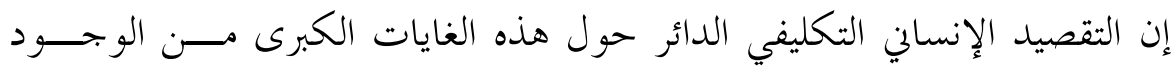
البشري، لا تمر إلا عبر تمثلات واقعية، وتشخيصية للقيم الإنسانية المطلوب العناية هها، والاهتمام بقدرها علماً وعملاً.

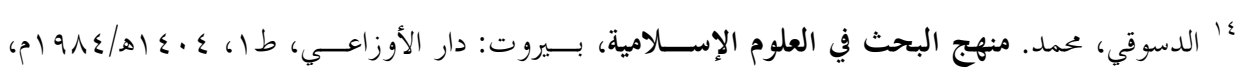

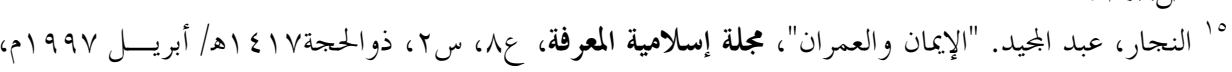




\section{ثالثاً: تطور العلوم، من العلوم الأصلية إلى علوم أصولها}

كانت العلوم الستة المذكورة، تمثل أمهات العلوم في تاريخ الفكر الإسلامي، التي

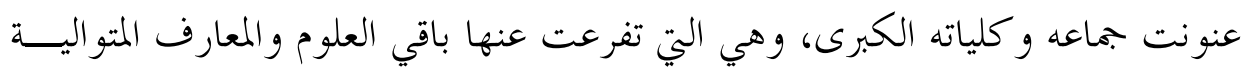

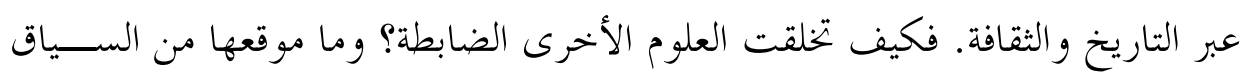

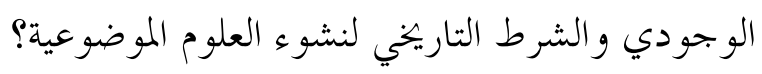

\section{ا ـ من فقه الحياة إلى فقه الأصول:}

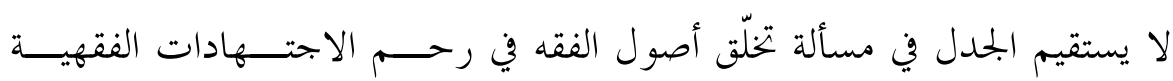

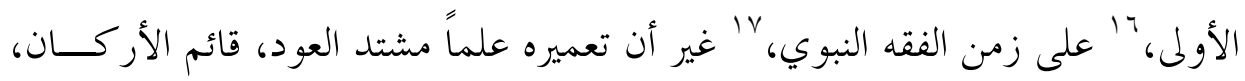

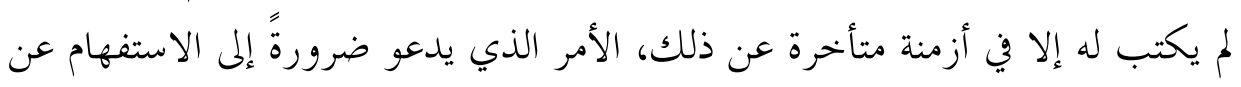
دواعي البحث في هذا العلم، ومسوغاها، وإمكانات استمر ارها عبر تاريخ العِلْمين.

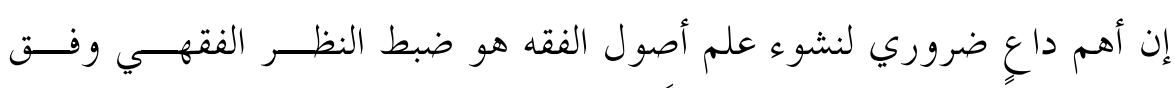

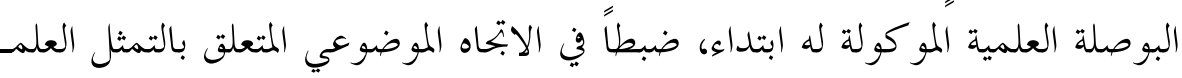

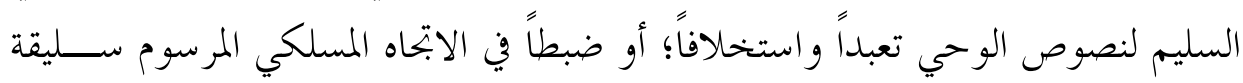

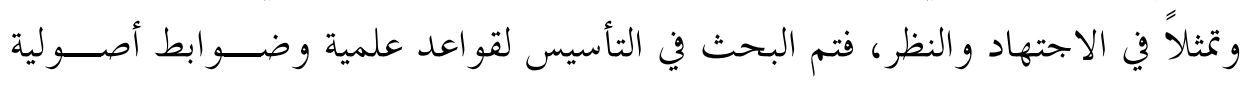

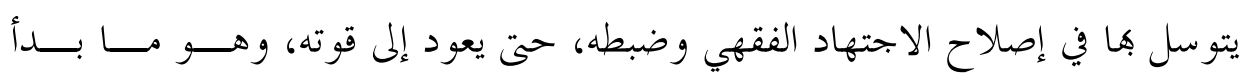

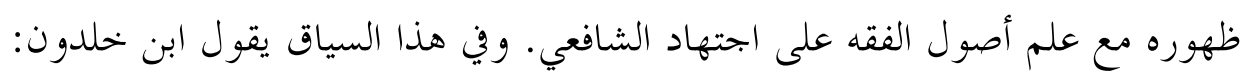

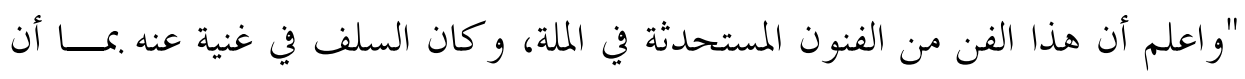

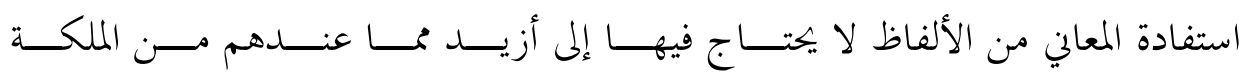

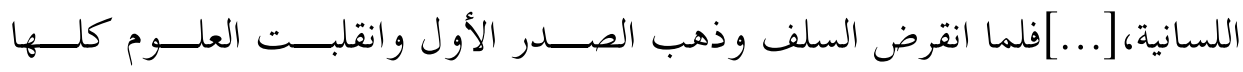

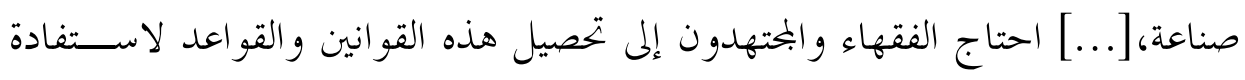

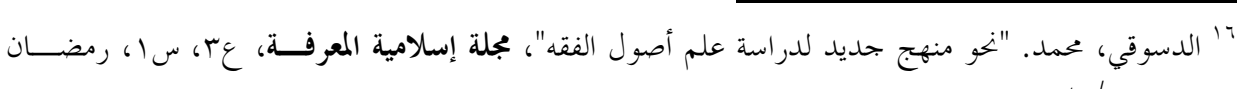

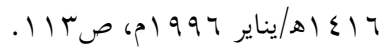
"ا' الزركشي، بدر الدين. البحر الخيط في أصول الفقه. تحقيق: محمد محمد تامر، بيروت: دار الكتب العلميــة،

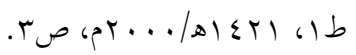




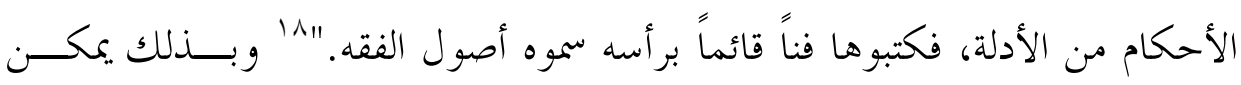

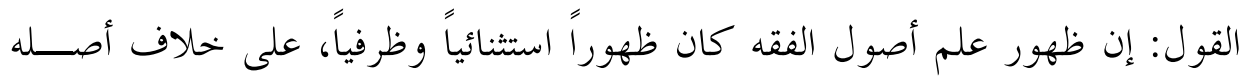

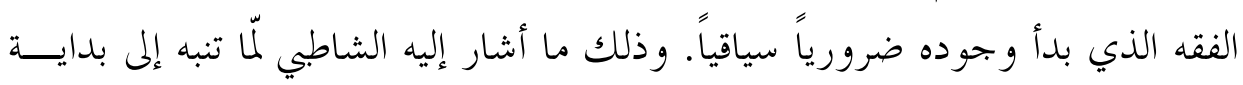

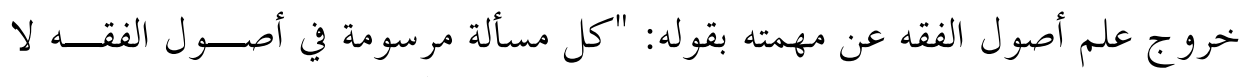
ينبين عليها فروع فقهية أو آداب شرعية أو لا تكون عوناً في ذلك، فوضعها في في أصول

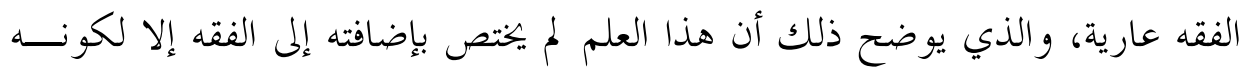

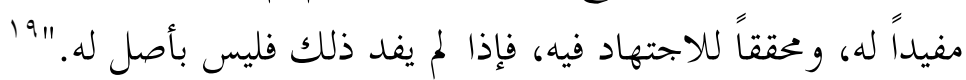

\section{Y. من تفسير النص إلى أصول التفسير:}

مع تو الي الأزمان وتباعد المسافات الوقتية عن مرحلة النبوة، التي نشأ فيها علـــم

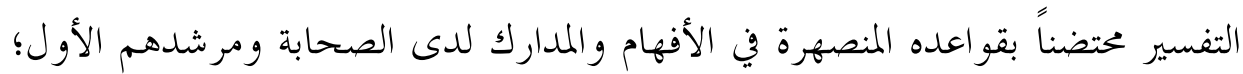

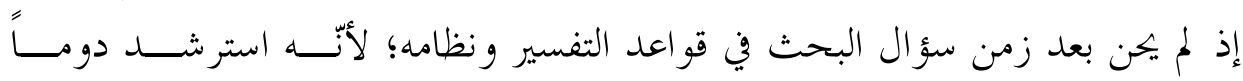
بالتوجهات النبوية، أضحى تفسير النصوص وفهمها يشكو -بسبب ضعو ضعف استــمرار

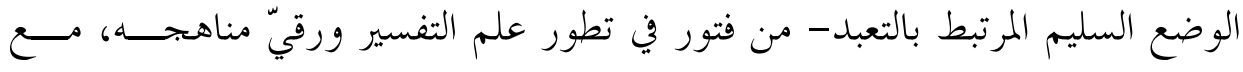

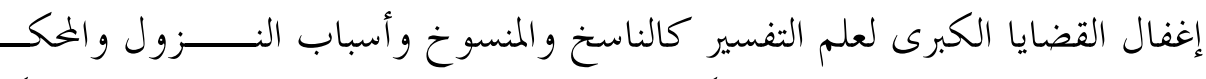
و المتشابه وغيرها، و كان ذلك سبباً من دواعي ظهور مدونات تنحو منحى" منهجياً في ترشيد النظر الباني و التفسيري، كتدوين ابن تيمية لمقدمة "تتضمن قواعد كلية تعــين

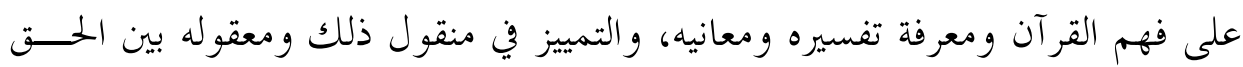

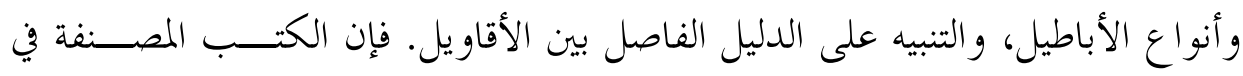

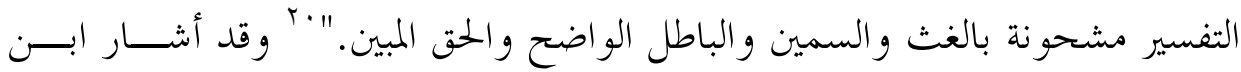

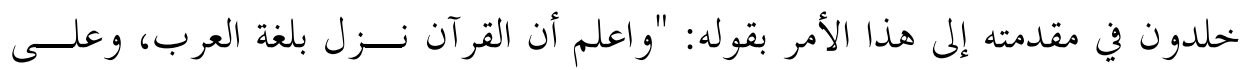
أساليب بلاغتهم، فكانوا كلهم يفهمونه ويعلمون معانيه في مفرداته وتراكيبـهـ... و لم

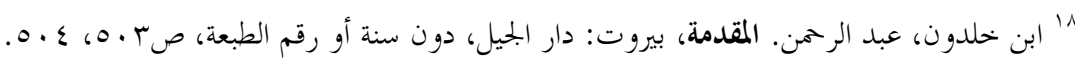

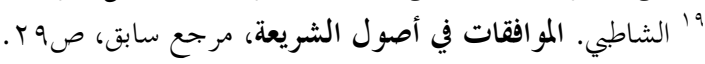

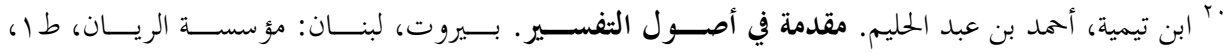


يزل متناقلاً بين الصدر الأول و السلف، حتى صارت المعارف علوماً، ودونت الكتب، الكما،

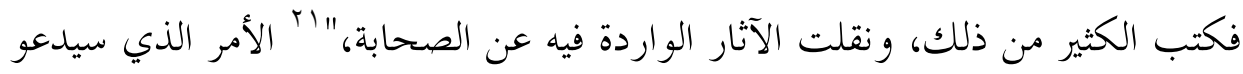

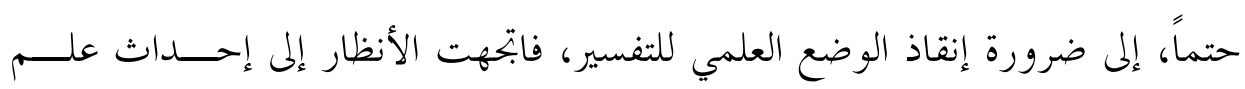

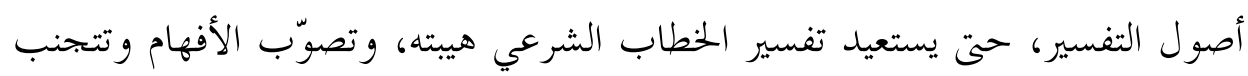

\section{ب. من اعتقاد الأصول إلى أصول الاعتقاد:}

قضية العقيدة كما القضايا الفقهية العملية، استصحبها الإنسان المسلم في تــاريخ

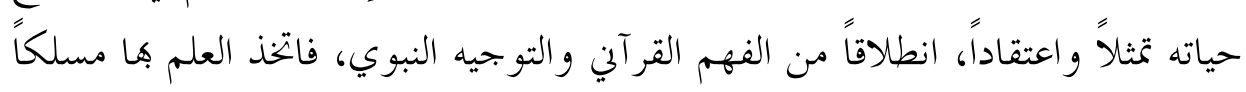

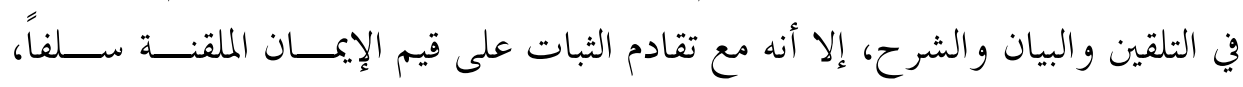

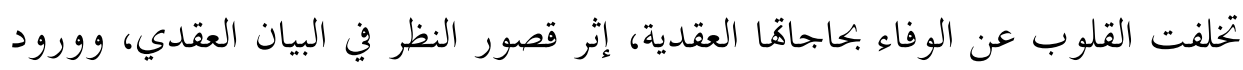

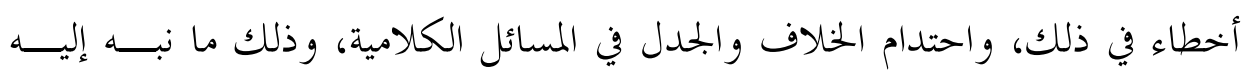
الأشعري عازماً على التأليف في قو اعد علم العقيدة؛ إذ قال: "فإنه لا بدّ لمن أر اد معرفة

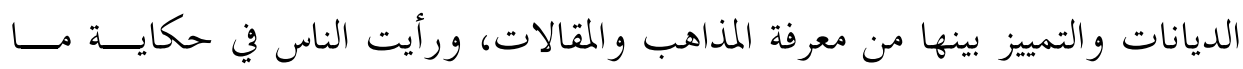

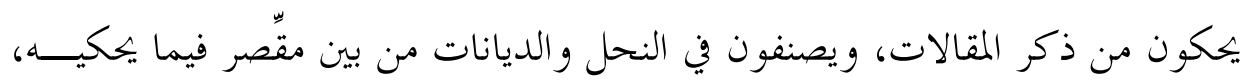

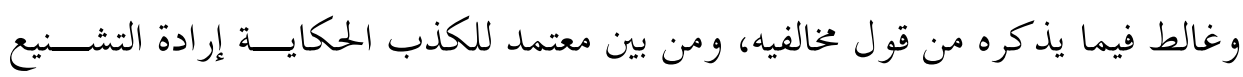

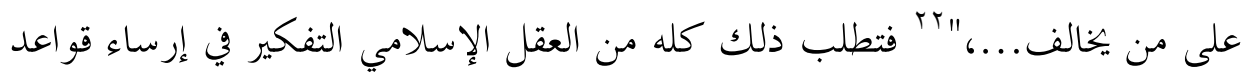

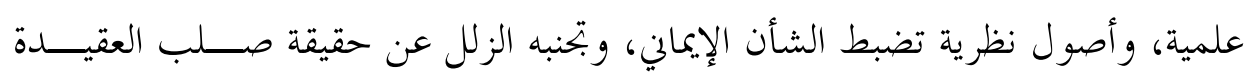

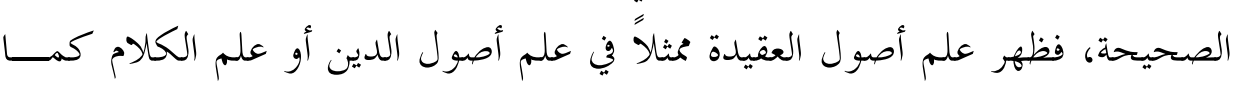

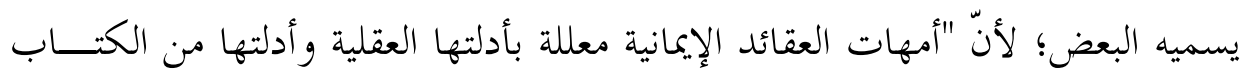
و السّنة كثير، وعن تلك الأدلة أخذها السلف وأرشد إليها العلماء وحققها الأئمة، إلا لإيها

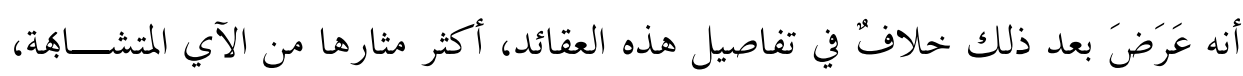

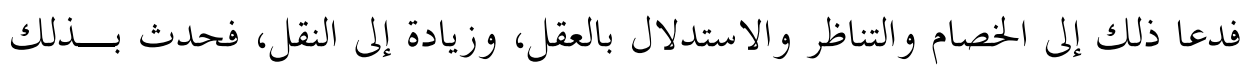

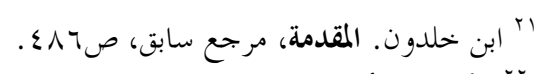

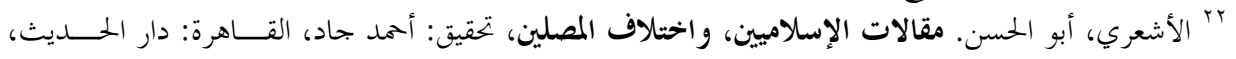
. A 
علم الكلام،" "rºاعتبر بذلك وجهة ضرورية في الإصلاح و التمكن من ناصية الســبيل السوي و القوي في تصحيح الاعتقاد.

\section{ع. من ورود الحديث إلى علم أصول الحديث:}

لقد أسهم الإشراف النبوي المباشر على فقه الحديث وتفسير النص القــــآني، في فهمها الفهم السليم، الذي يخدم مقاصد التعبد والاستخلاف والثهود الإنساني. كما كان لذلك الإشراف الكلمة الفصل في التحكيم النبوي لقضايا المسائل الطارئة علــى

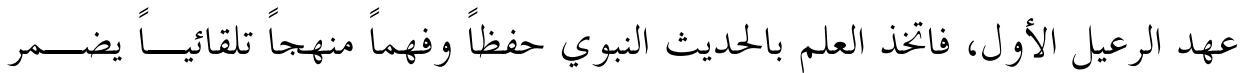
أصولاً وقواعد لا تحتاج إلى إثباها بالنظر وبياها بالتدليل، بل إن إن التحكيم النبوي أرجأ

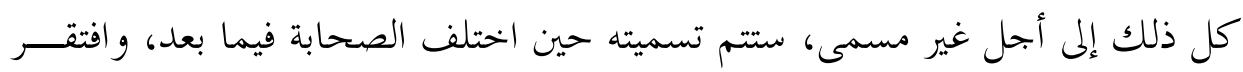
إلى الأسانيد الصحيحة التي تضمن صحة الحديث و سلامة فهمه.

فلما كثر الوضع وشكك في أقوال منسوبة إلى المخكم الأول، ابتحه العقل المسلم إلى

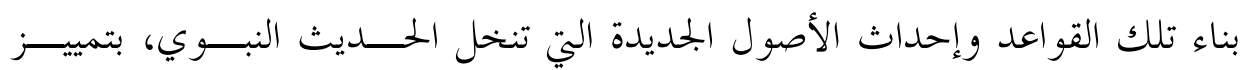

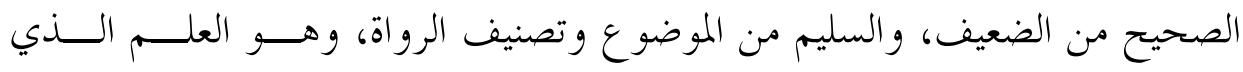
اصطلح عليه علم أصول الحديث.

\section{ه. من استثمار اللغة إلى ضبط اللغة:}

ما حدث لباقي العلوم حدث لعلم اللسان العربي، وتمثلاته الفعلية في فقه الخطاب الشرعي، من حيث التبادل العلمي في الحفظ والرعاية. غير أن التغيرات التاريخية الــتي حصلت بلمتمع ما بعد العهد النبوي على الخصوص، من تو افد ألسنة جديدة على المحال

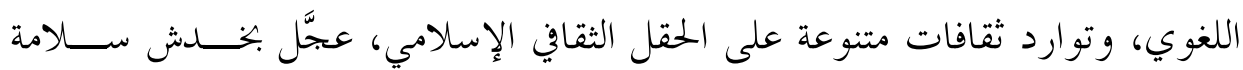
اللسان العربي، كما لحقها ما يعرف باللحن والفساد المؤثرين في ذلك الحفظ المتبادل. يقول ابن خلدون في بيان السياق التاريخي لنشأة علم أصول اللغة: "ثم صارت علــــوم

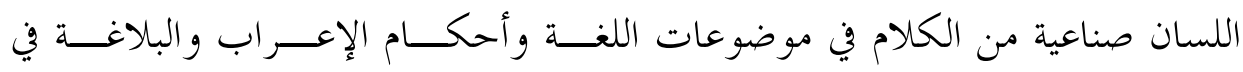


التراكيب، فوضعت الدواوين في ذلك بعد أن كانت ملكات للعرب لا يرجع فيها إلى

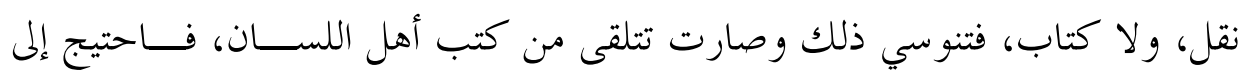

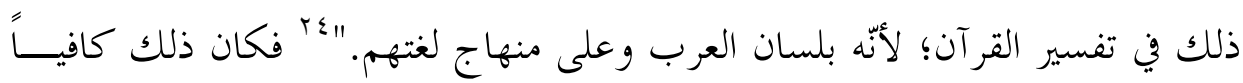

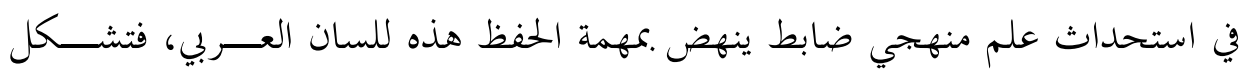

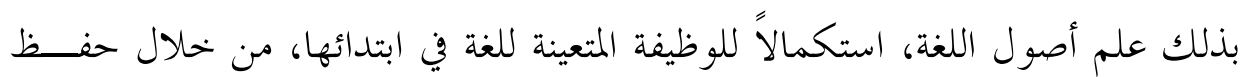
لساها المو كل له ذات الوظيفة. يقول الجرجاني في رفعة قدره: "وهو باب من العلم إذا أنت فتحته اطلعت على فو ائد جليلة ومعان شريفة، ورأيت له أثرًا في الدين عظيمــاً،

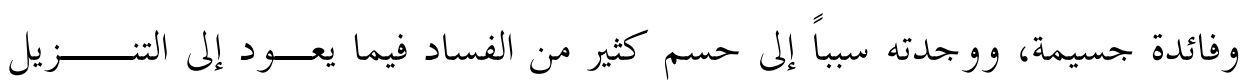

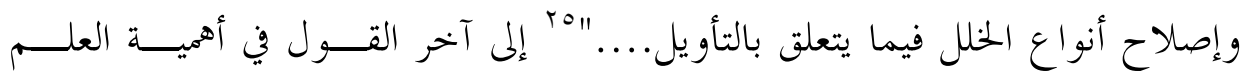
بالقواعد اللغوية ومبادئها القيمة على سلامة اللسان العربي.

\section{رابعاً: مقارنة بين العلوم الأصلية و العلوم التبعية}

\section{ا ـ العملية و النظرية:}

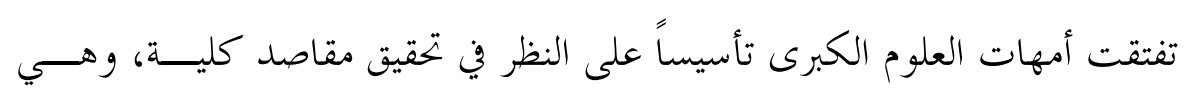

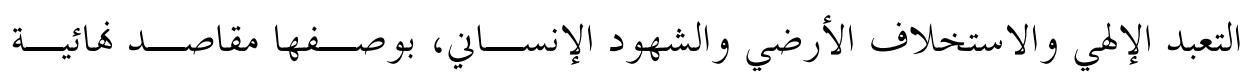

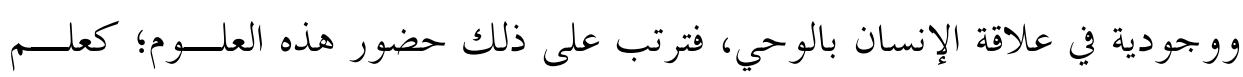

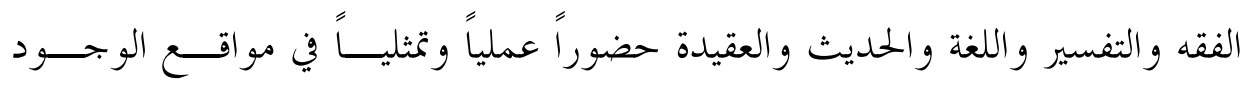

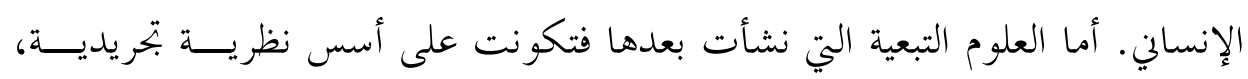
تبحث في تحقيق غايات و جودية لتلك العلوم و خدمتها ليتم التمكن فيها، فغلب عليها

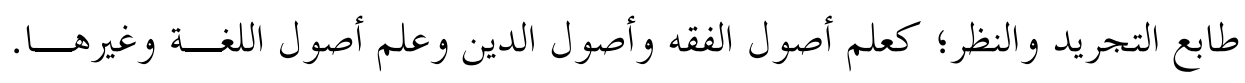

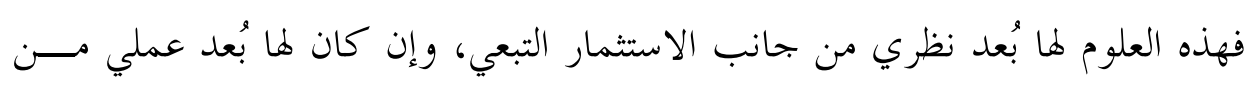

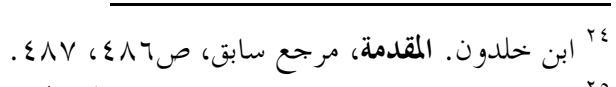

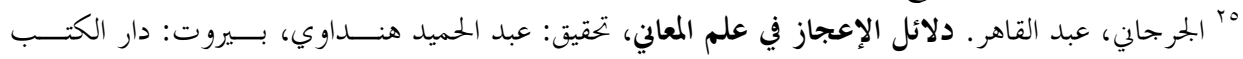




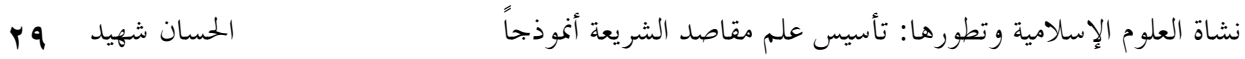

جانب القصد الأصلي. وفي السياق نفسه يرى ابن خلدون أن مسائل علــــم الكـــلام

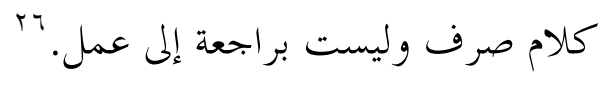

\section{ץ. في القصدية والآلية:}

المراد بخاصيتي القصدية والآلية؛ هو أن هناك علوماً ارتبط النظر فيها بالقصد الأول

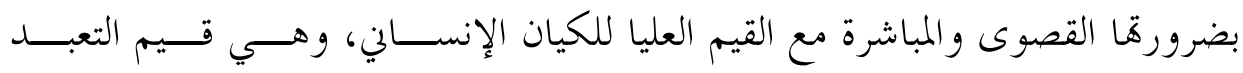

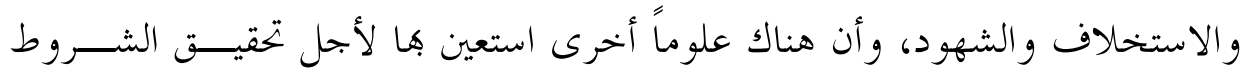

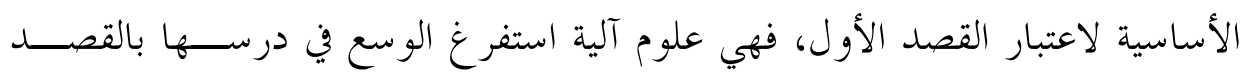
التبعي لا الأصلي، وذلك ما أشار إليه ابن خلدون بقوله: "وهذا كما فعل المتـــأخرون

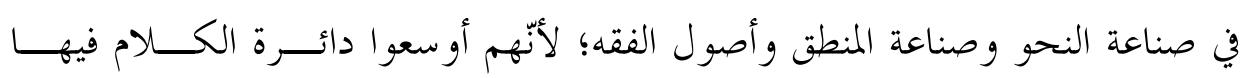

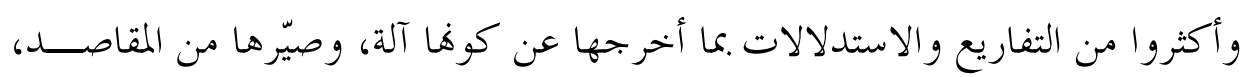

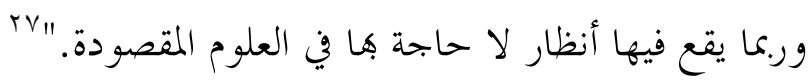

\section{ب. في القر اءة و التصحيح:}

توجه العقل المسلم إلى النظر في كتاب الوحي بقصد قراءتــهـ قــــاءة تســتجيب لمتطلباته الإنسانية والوجودية، و بيان مقتضياها المعرفية في التمثل، فتمخض عبر تلـــك

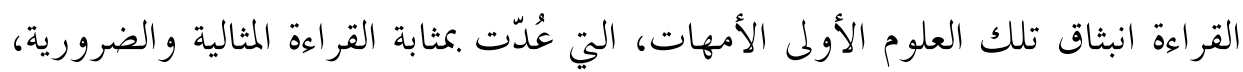
غير أن دواعي الزمن بكل تداعياها الاجتماعية والمعرفية وغيرها، انحرفت بتلك القراءة عن مسارها المستقيم ومقاصدها المرسومة، فتطلّب الأمر النظر في تصحيح تلك العلوم القارئة وإنقاذها من الزيغ، وتكفلت العلوم المنهجية الآلية بأداء تلك المهام المو كلة إليها والمتعلقة هـا.

فعلوم الأصول؛ أصول الفقه وأصول الحديث وأصول العقيـــدة وأصـــول اللغـــة

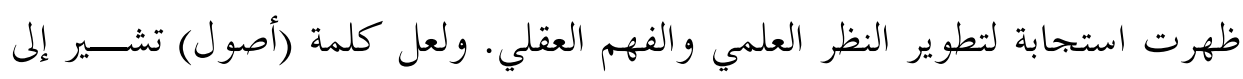

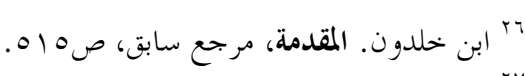

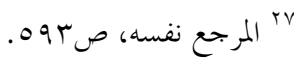




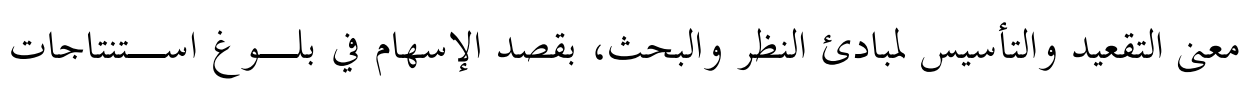
صائبة و اجتهادات صحيحة.

أمام هذا المشهد التاريخي للعلوم، هل هناك من إمكانية في استحداث علوم أخرى جديدة؟ وما موقع دعوات النظر في تأسيس علوم جديدة كعلم المقاصد مثلاً؟ هئ

خامساً: إثكال تأسيس علم جديد هو "علم المقاصد" 1. في دعوى استقلال المقاصد:

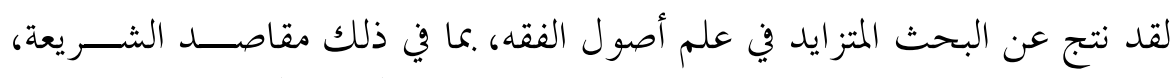

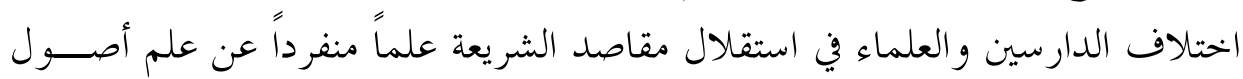

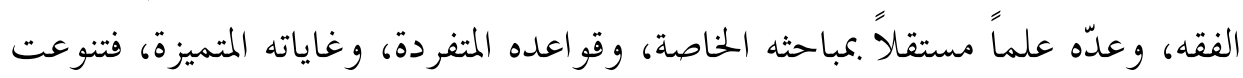

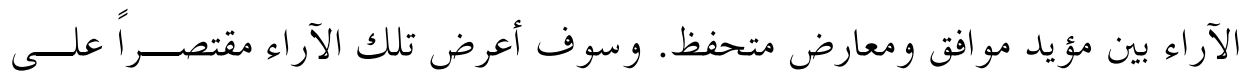

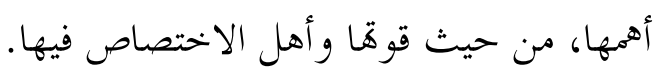

أما الاتجحاه الأول، فتعود انطلاقة موقفه إلى الشيخ الطاهر بن عاشــور في كتابــــ "مقاصد الشريعة"، الذي دعا فيه إلى إعادة صو غ مسائل أصول الفقه المتعارفة، ووضع أشرف معادن الفقه فيها، باستخلاص علم جديد هو علم مقاصد الشريعة، فهو يقول: "فنحن إذا أردنا أن ندوّن أصولاً قطعية للتفقه في الدين حق علينا أن نعمد إلى مسائل

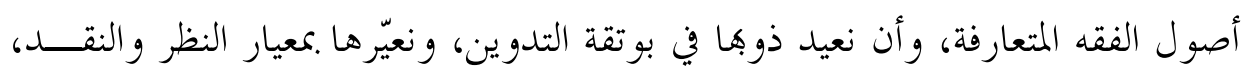

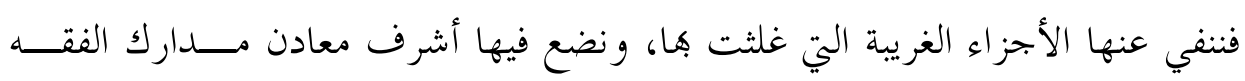

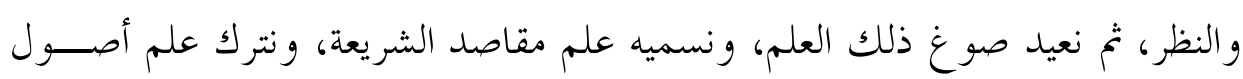

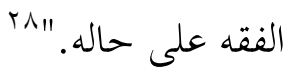

و يبدو أن داعي الشيخ ابن عاشور إلى هذا القول مردّه إلى إرادة تدوين أصسـول

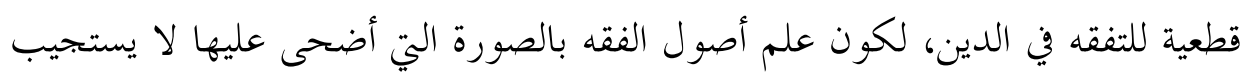

11 ابن عاشور، الطاهر. مقاصد الشريعة الإسلامية. تونس: الشركة التونسية للتوزيع، 911 19، ص111. 
للمعاني القطعية في ذلك التفقه، من حيث ورود الخلاف على أغلب مسائله، وإلحــــاق أجزاء مهمة منها بمر اتب الظنيات.

وقد كان هذا الرأي مظنة ارتياح لدى الشيخ أحمد الريسولي، وإن لم يتم الإفصاح عنه بصورة واضحة، فقال: "هل سيفضي بنا التوسع في مباحث المقاصد على تحقيق ما دعا إليه الشيتخ محمد الطاهر بن عاشور من استخلاص مقاصـــــ الــــين وقطعياتـــه، وتسمياتا باسم علم مقاصد الشريعة، أم أن المقاصد جزء لا ينبغي أن يتجزأ عن أصول

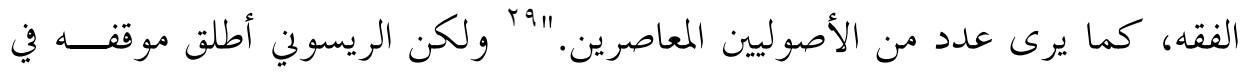
علمية المقاصد واستقلالها، ثم قيده بوصفه ركناً من علم أصول الفقه فقال: "فالمقاصد المد

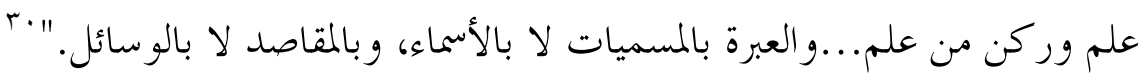
الاتحاه الثاني: يتحفظ من تلك الدعوى الداعية إلى استقلال المقاصد الشرعية عن علم أصول الفقه. ومن أبرز رواد هذا الاتجاه جمال الدين عطية، الذي يدعو إلى عـــدم

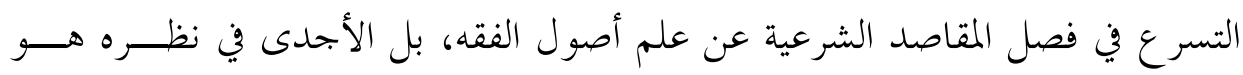

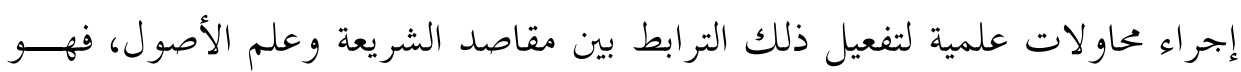

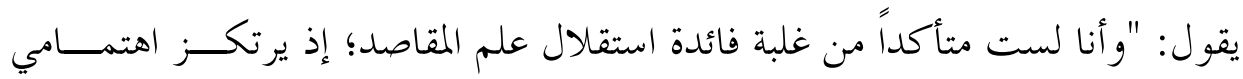

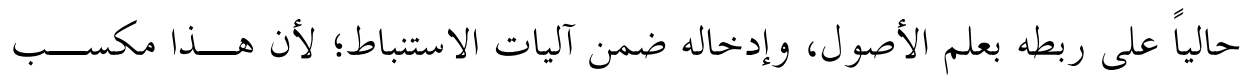

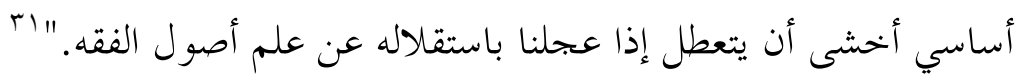

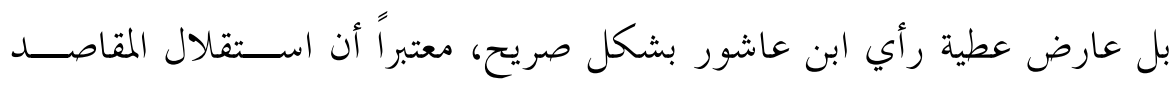

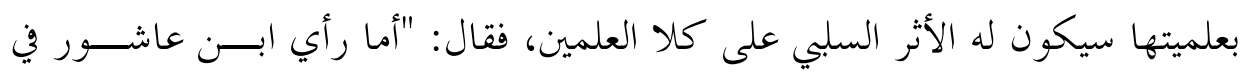
تأسيس علم مستقل لمقاصد الشريعة وترك علم أصول الفقه على حاله، فأرى أنه ضار بكلا "العلمين"؛ إذ يجمّد الأصول على حالها ويمرمها من روح المقاصد، كما أنه يبعد

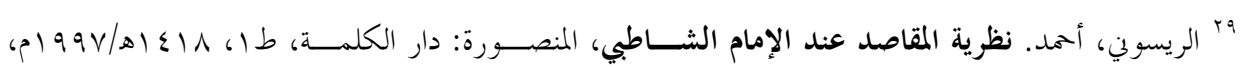

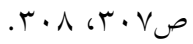

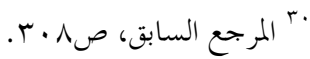

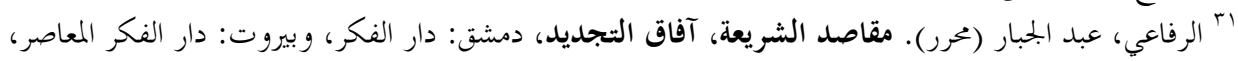

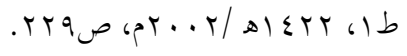




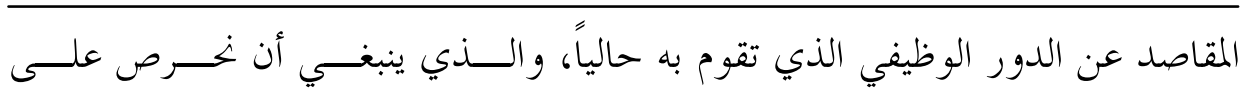
تطويره.

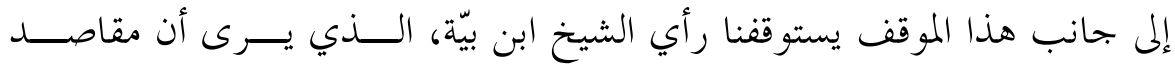

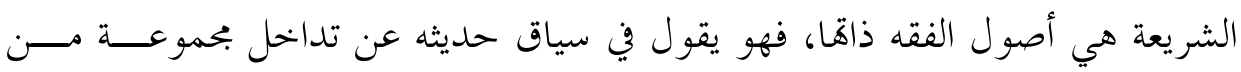

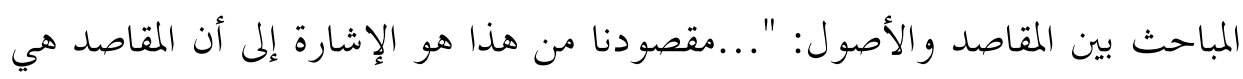

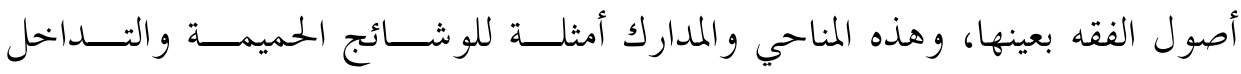

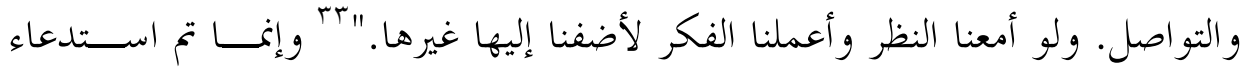

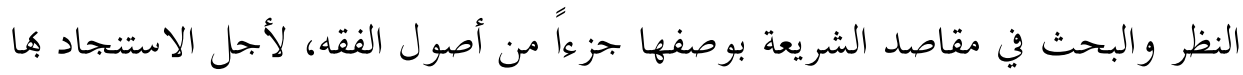

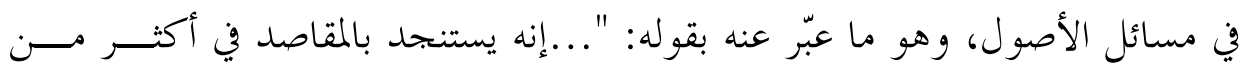

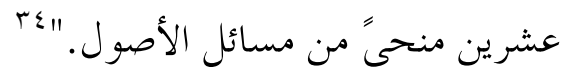

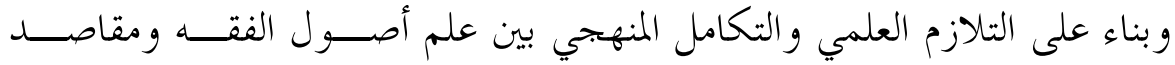

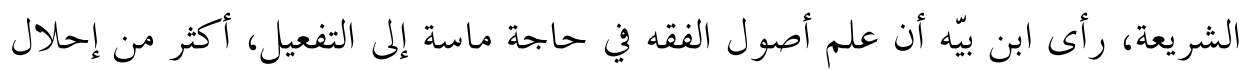

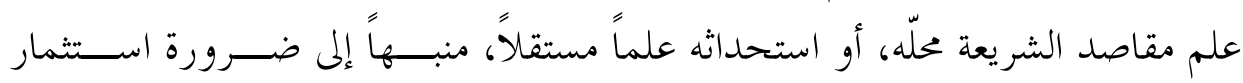

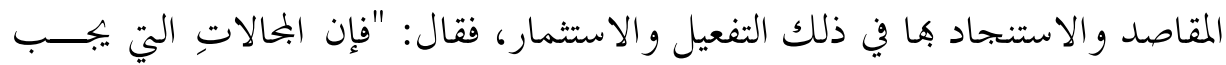

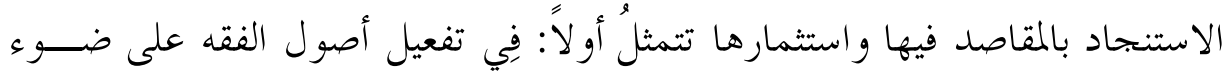

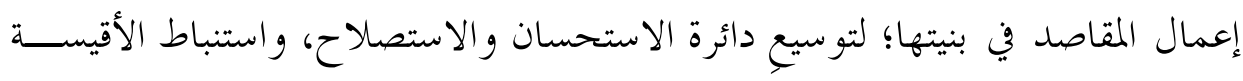

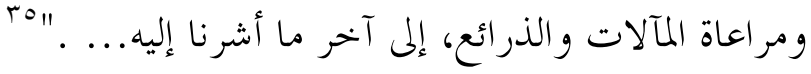

وهذا الاتحاه يحتفظ لنفسه برأي عدم إقالة مقاصد الشريعة من حمى علم الأصول،

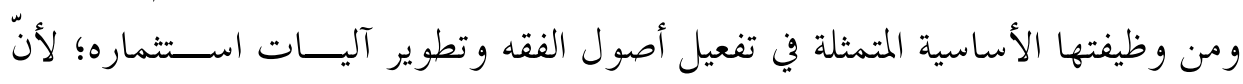
ذلك سيؤثر -لا محالة- على روحه التشريعية.

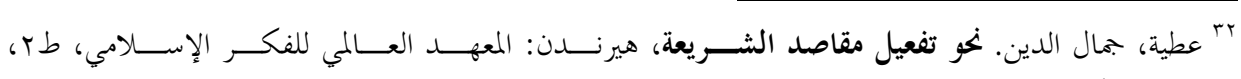
年

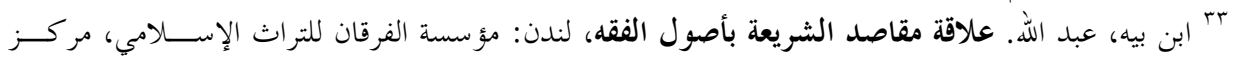

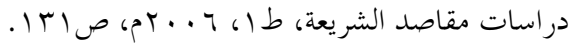

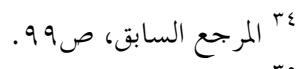

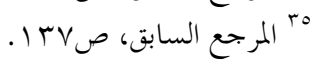




\section{r. بؤية ذاتية في إشكال استقلال المقاصد:}

تأتي الدعوة في اعتقادي إلى تأسيس علم جديد نابع من علم أصول الفقه من عدم

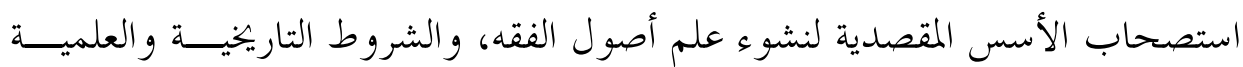

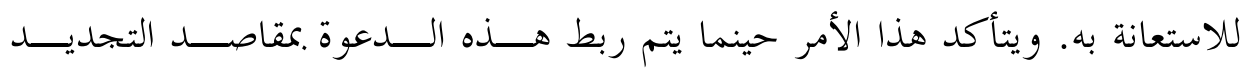
الاجتماعي والحضاري في كيان الأمة، لذلك فإن النظر في هذا الاختيار العلمي ينبغي أن يحمل على السياق التاريخي الذي نشأت فيه تلك الدعوة.

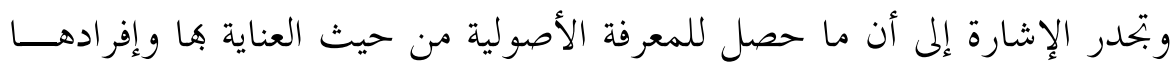
بالدراسة والبحث، هو ما يحصل في الآونة الأخيرة مع المعرفة المقاصدية؛ فأصول الفقه الإنه

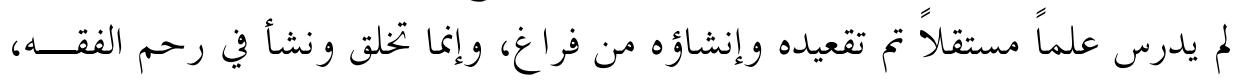

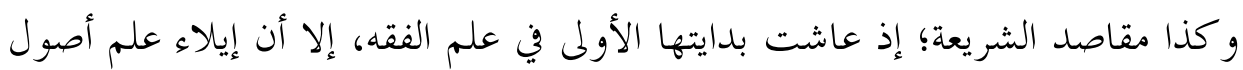

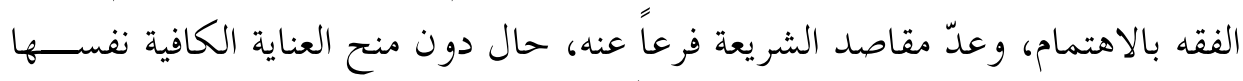

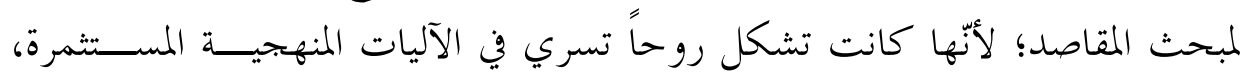

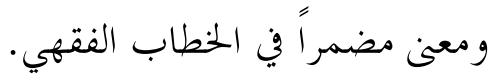

لذلك فإن بتربة الانبثاق العلمي لأصول الفقه، واستقلاله المعرفي مـــن جوانـــبـ

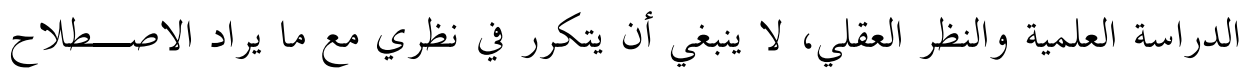
عليه "بعلم مقاصد الشريعة"، و ذلك لأسباب أذكرها على سبيل الإيجاز ، وأهمها:

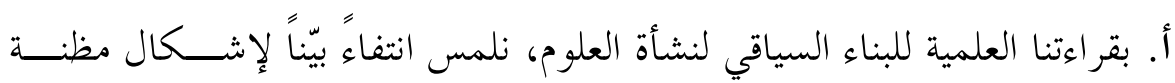

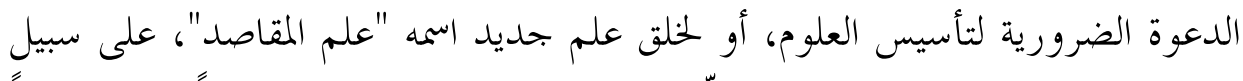

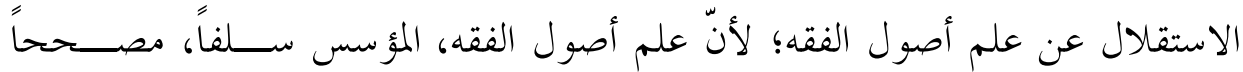

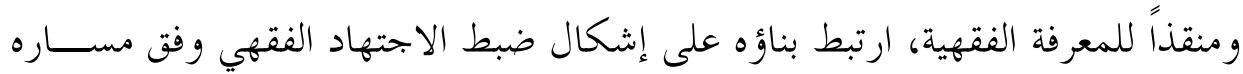

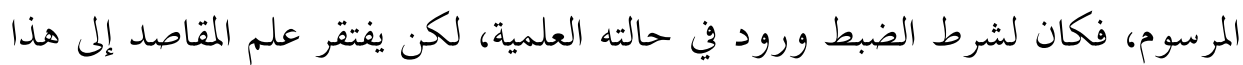

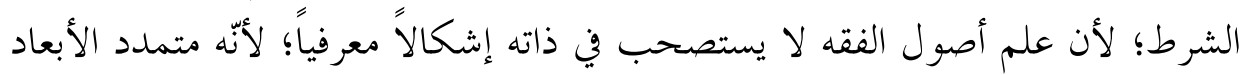

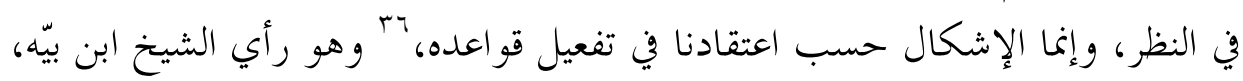
ثم كذلك في الغياب النظري لإعماها واستثمارها، ومبادئ المقاصد جزء من ذلك. بr وهو رأي أستاذنا ابن بيه السابق الذكر. 


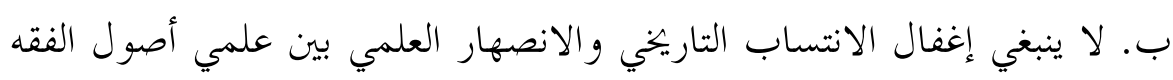

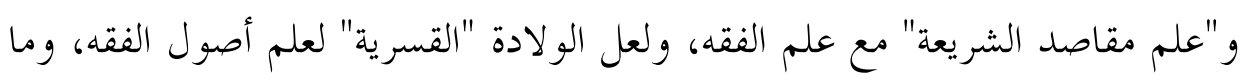

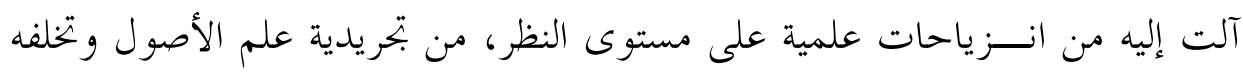

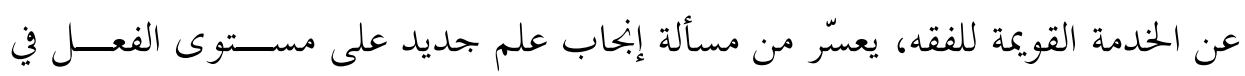

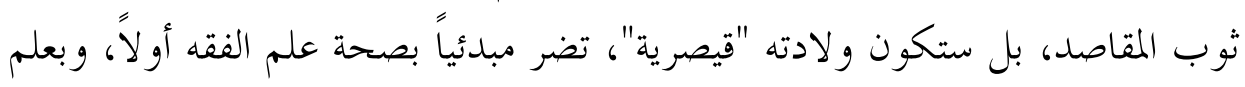

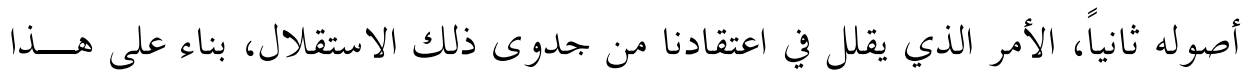
النــزيف العلمي المتسلسل.

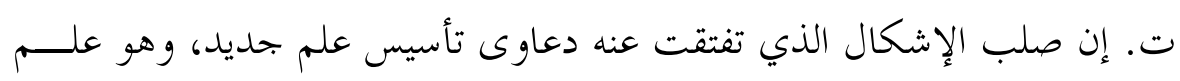

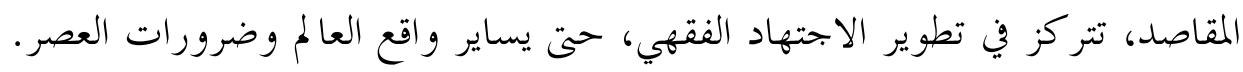

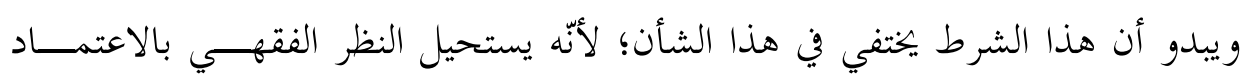

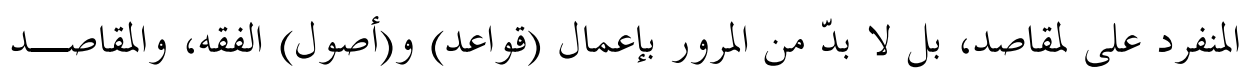

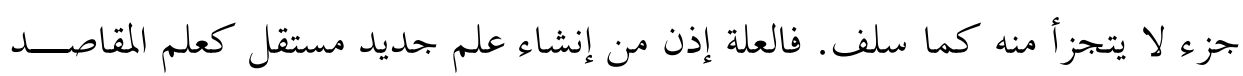

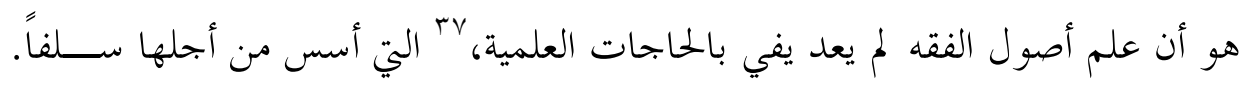

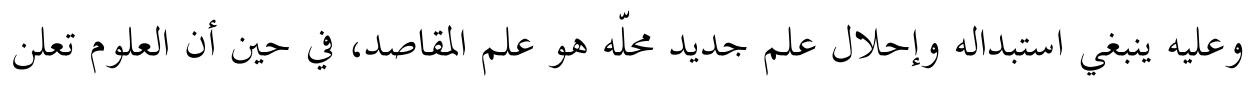

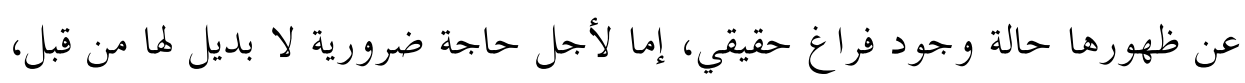

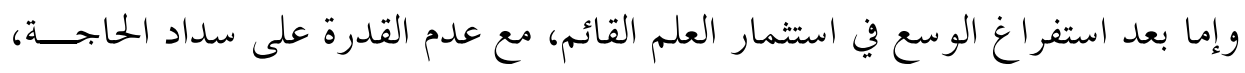

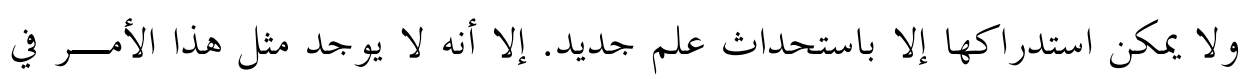

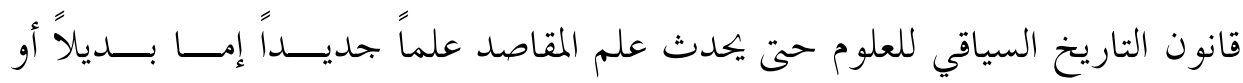

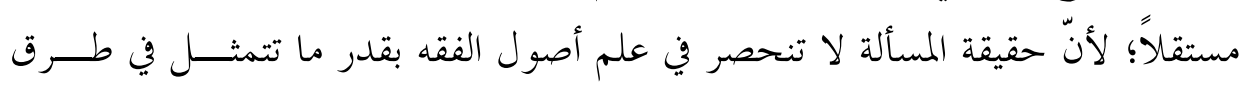
تفعيله، واستثمار جميع قو اعده، بما في ذلك قو اعد النظر المقصدي.

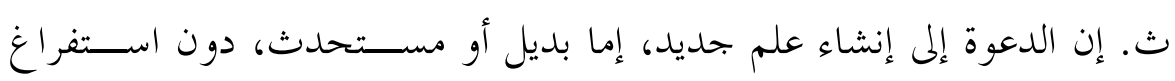

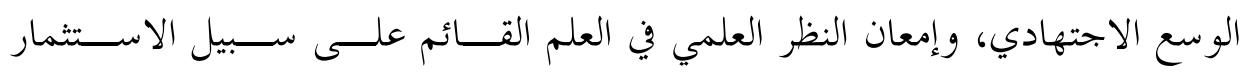

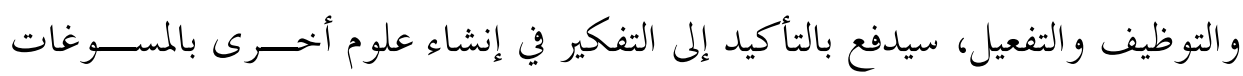


نفسها والحيثيات المذكورة سلفاً، وإن لم تدع الضرورات العلمية إليها، سواء كانـــت

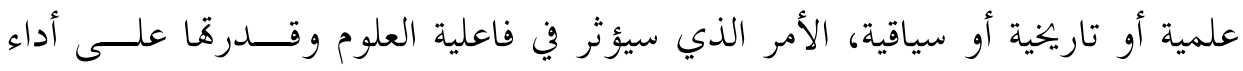
مهمتها التي لأجلها أنشئت، لذلك فإن خصوصية التحفظ من منطق التفكير التأسيسي للعلوم تضمر في الغياب من جانب الوجود.

كانت هذه أهم الشروط العلمية في نظرنا التي تفتقر إليها دعاوى إنشـــاء علــــم جديد هو علم المقاصد، أو جعله بديلاً عن علم أصول الفقه.

ومع كل ما ذكر، فإنه لا ينبغي أن يفهم من كلامنا على -سبيل القطع - ميلنا إلى تجنب تحقيق النظر في المباحث المقاصدية في استقلال عن علم أصول الفقه، فذلك أمر قد حصل بإفراده بالبحث مع بعض الأصوليين كالعز بن عبد السلام و الشاطبي، وإنمـــا

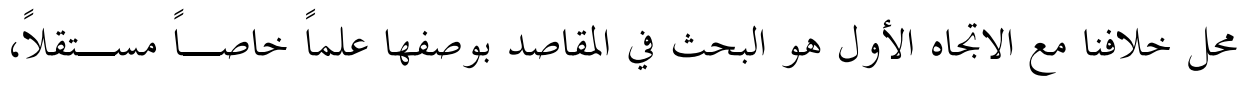

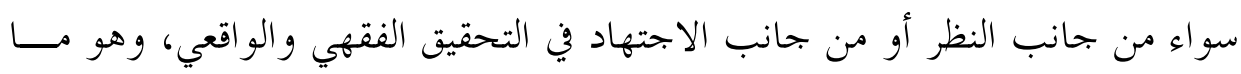

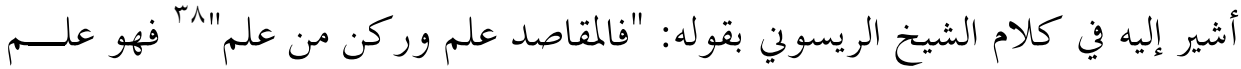

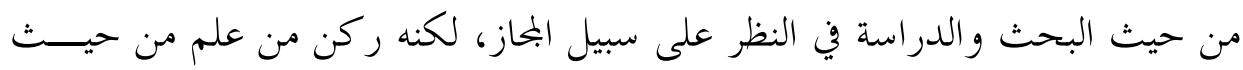
الاجتهاد و التنــزيل في الو اقع على سبيل الاختصاص و الحقيقة.

خاتمة:

لقد أنتج الزمن الإسلامي علوماً كبرى مقصودة لذاها، بالنظر المبين على العمـلـ لحسل

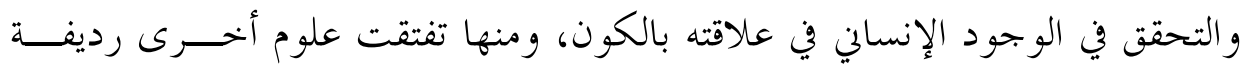

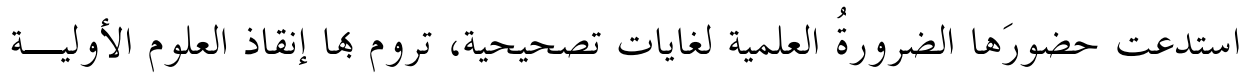

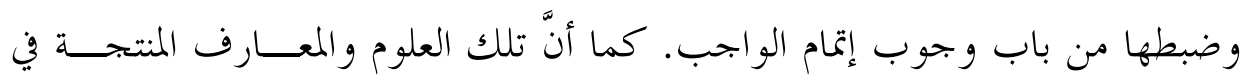

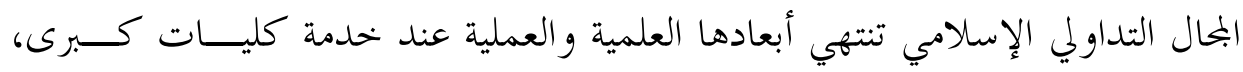
ومقاصد عظمى من الوجود الإنساني من القراءة السليمة لعالمي الوحي والكون، وتلك لك المقاصد هي التعبد الإلهي والاستخلاف الأرضي والشهود الإنساني. 


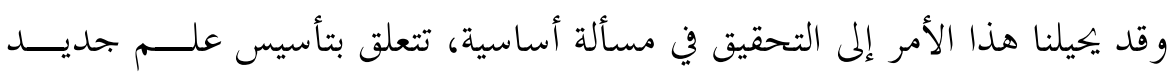
كعلم المقاصد مثلاً، الذي اختلف فيه الدارسون و المحققون بين مؤيد ومعارض. وفيل ويبدو في نظرنا أن ابتحاه الاعتر اض على الدعوى يترجح عن مقابله، وأولى بالاعتبار، بـــالنظر إلى تداخل أسباب ورد ذكرها في متن هذه الدراسة.

حسبُ هذه الدراسة أها أسهمت في إيراد إشكال نشأة العلوم وتطورها، وفهــم

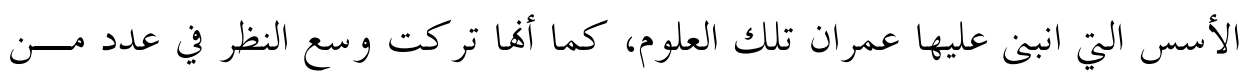

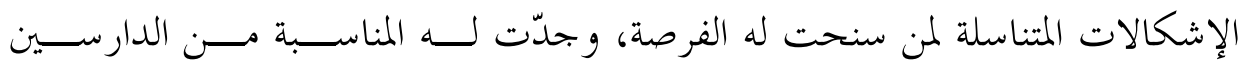
و الباحثين، ولعل من المناسب البحث في الإشكالات الآتية:

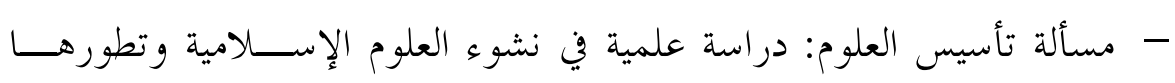
دراسة مستفيضة تكشف عن الأسس العلمية و المنهجية المعتمد عليها في نشأة العلوم. - العلوم الإسلامية والقيم المقصدية في مواقع الوجود، بحث في المقاصد الكليــة

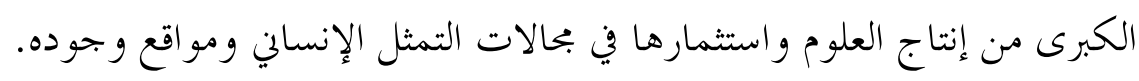

- استقلال علم المقاصد بين السياق المنهجي والضرورة العلمية، دراسة علميــة تاريخية في دعاوى استقلال علم المقاصد ومدى صحتها وقوقا في الاستمرار و النجاح، و آليات الاشتغال على المنهح المقاصدي على سبيل الاستقلال. 